\title{
THE RHETORIC OF ADVANCEMENT: ARS DICTAMINIS, CURSUS, AND CLERICAL CAREERISM IN LATE MEDIEVAL ENGLAND
}

\author{
Ian Cornelius
}

\begin{abstract}
A clerk writes to a bishop. ${ }^{1}$ He expresses gratitude for past support and A measured hope that, through continued service under the bishop's protecting wing, he might merit still greater rewards in time to come. More specifically, the clerk submits his desire to serve in the Queen's household, in a capacity conducive to the advancement of his status ('pro mei status incremento congruum [...] et oportunum'). In reply, the bishop reports that he has secured for his clerk the position of secretary to the Queen's seneschal, a position with good opportunities for subsequent promotion ('per quod quidem officium [...] gradum attingere poteritis alciorem'). In closing, the bishop petitions the Lord God to allow the letter's recipient to climb to exactly the desired point: 'qui vobis concedat ad punctum scandere peroptatum'. In the context of the letter exchange, this closing must be a petition for the success of the recipient's career. At least in
\end{abstract}

${ }^{1}$ Letter 13 in the formulary accompanying Simon O.'s Ars dictandi, printed in W. A. Pantin, 'A Medieval Treatise on Letter-Writing, with Examples, from Rylands Latin MS 394', Bulletin of the John Rylands University Library of Manchester, 13 (1929), 326-82 (p. 347). The reply is Letter 14. For a possible continuation to the story, see the letters between a clerk and a friend, nos 45 and 46. Translations are mine unless otherwise noted.

Ian Cornelius (ian.cornelius@yale.edu) is Assistant Professor of English at Yale University.

Abstract: This article examines the medieval ars dictaminis, or art of letter-writing, focusing on sociocultural aspects, especially as taught at Oxford c. 1370-1432. Ars dictaminis participated in and contributed to a structural transformation in the production of written communications and administrative records in later medieval Europe. Two aspects of this transformation were the recruitment and educational formation of a class of domestic literate servants, and a diversification in the field of educational alternatives. Teachers of ars dictaminis recognized and responded to these aspects of their pragmatic situation: in addition to providing technical instruction, the ars dictaminis provided its students and practitioners with normative representations of their location within a stratified social world. In several textbooks of English provenance, instruction in cursus, or prose rhythm, became an occasion for working out this discipline's contested status within the symbolic economies of education and patronage.

Keywords: ars dictaminis, letter-writing, rhetoric, cursus, Oxford University, education, business training, secretaries, professional literacy, patronage, sociological methods. 
the first instance. For the letter's last word - 'peroptatum' (most desired) exerts a retroactive force on the meaning of the valedictory formula that it concludes, transforming this valediction into a petition for the salvation of the recipient's soul. It will be noticed that the reorientation from matters of professional advancement to matters of eternal salvation occurs only by presenting salvation as the greatest of all promotions. More importantly, the easy transition from the one to the other implies that the clerk's initial request, while worldly, is not mundane.

\section{'Ars dictaminis' and Clerical Careerism}

The royal administration and the great houses of the gentry were destinations both coveted and regularly achieved by medieval scholars. ${ }^{2}$ Stressing the importance of royal patronage for university graduates, William Courtenay writes that '[f] or many (and probably as an ideal for most) the university led to a career that moved toward London as surely and unalterably as the water that flowed under the bridges outside Oxford'. ${ }^{3}$ Courtenay's statement means that, prior to institution of salaried lectureships, the universities were typically only an important stage in a scholar's career, to be continued elsewhere. Moreover, 'elsewhere' was perhaps as likely to lie in what we might call the professions - administration, chanceries, courts of law - as it was to lie in a parochial living. ${ }^{4}$ (Often, ecclesiastical and lay patronage would be intertwined.) Aspirational trajectories, in which study leads to a professional appointment, are illustrated by medieval letters. ${ }^{5}$ Many

${ }^{2}$ On careers and patronage of scholars, see William J. Courtenay, Schools and Scholars in Fourteenth-Century England (Princeton: Princeton University Press, 1987), pp. 118-46; and T. A. R. Evans, 'The Number, Origins, and Careers of Scholars', in The History of the University of Oxford, II: Late Medieval Oxford, ed. by J. I. Catto and T. A. R. Evans (Oxford: Clarendon Press, 1984), pp. 519-38.

${ }^{3}$ Courtenay, Schools and Scholars, p. 118.

${ }^{4}$ Evans, 'The Number, Origins, and Careers of Scholars', p. 538.

${ }^{5}$ In addition to the letters cited in note 1 , above, see Letters $3,4,7,8,54,55,56$, and 75 in Pantin, 'A Medieval Treatise on Letter-Writing'; Letters 20, 21, 26, 27, 47, 55, 56, 57, 58, 70, and 81 in H. G. Richardson, 'Letters of the Oxford Dictatores', in Formularies Which Bear on the History of Oxford, c. 1204-1420, ed. by H. E. Salter, W. A. Pantin, and H. G. Richardson, Oxford Historical Society, n.s., 5, 2 vols (Oxford: Clarendon Press, 1942), II, 329-450; and Letters 15, $16,17,18$, and 31 in the letter collection appended to the treatise Regina sedens rhetorica, ed. by Martin Camargo, in Medieval Rhetorics of Prose Composition: Five English 'Artes dictandi' and their 
such letters concern appointments to church benefices; others concern appointments in households of the lay nobility and gentry. Similarly, a letter from a familial sponsor to a young man studying at university might end with the reminder that study should bring material benefits to both the student and his family. ${ }^{6}$ When assembled into collections (formularies) and appended to manuals of letter-writing (artes dictandi) these letters served as illustrations of correct epistolary style. ${ }^{7}$ Hence, a student might encounter, within the materials that

Tradition, Medieval \& Renaissance Texts \& Studies, 115 (Binghamton, NY: Center for Medieval and Renaissance Studies, 1995), pp. 169-219 (Letters 15 and 16 share a theme and wording with Pantin, 'A Medieval Treatise on Letter-Writing', nos 55 and 56). For a slightly improved text of Richardson's Letter 81, as well as two petitions for benefices, see Camargo, Medieval Rhetorics, pp. 159-60. Petitions for professional appointments go largely unnoticed in Charles Homer Haskins's seminal study: see 'The Life of Mediaeval Students as Illustrated by their Letters', in Haskins, Studies in Mediaeval Culture (Oxford: Clarendon Press, 1929), p. 21; p. 9 n. 1.

${ }^{6}$ Compare Richardson, 'Letters', nos 23, 51, 80, 91, and 96; and Regina sedens rhetorica, ed. by Camargo, Letters 23 and 26. Jean Leclercq comments helpfully on the reciprocal material dependence of medieval students and their patrons: see Jean Leclercq, 'L'Amitié dans les lettres au moyen âge: Autor d'un manuscrit de la Bibliothèque de Pétrarque', Revue du moyen âge latin, 1 (1945), 391-410 (pp. 396-99). The politico-economic benefits of learning, recorded by Leclercq and in letters printed by Richardson, applied almost exclusively to men, who, in any case, had a near monopoly on formal educational opportunities outside of the nobility. For notice of surviving letters in the names of noble women in thirteenth- and fourteenth-century England, see William Rothwell, 'Stratford Atte Bowe Re-visited', Chaucer Review, 36 (2001), 184-207 (p. 190). On women's access to education during this period see (with further references) Alan B. Cobban, English University Life in the Middle Ages (Columbus: Ohio State University Press, 1999), pp. 1-2. On some implications of all-male schooling, see Marjorie Curry Woods, 'Boys Will Be Women: Musings on Classroom Nostalgia and the Chaucerian Audience(s)', in Speaking Images: Essays in Honor of $V$. A. Kolve, ed. by Robert F. Yeager and Charlotte Cook Morse (Asheville, NC: Pegasus, 2001), pp. 143-66; and Ralph Hanna III, 'School and Scorn: Gender in Piers Plowman', New Medieval Literatures, 3 (2000), 213-27.

${ }^{7}$ Throughout, I use the term ars dictaminis for the art or discipline or letter-writing and ars dictandi for the manuals or textbooks that taught letter-writing; this terminological distinction is proposed by Martin Camargo and does not reflect medieval practice: see Martin Camargo, Ars dictaminis, Ars dictandi, Typologie des Sources du Moyen Âge Occidental, 60 (Turnhout: Brepols, 1991), p. 20. On the medieval ars dictaminis see Camargo, ibid.; Franz Josef Worstbrock, Monika Klaes, and Jutta Lütten, Repertorium der 'Artes dictandi' des Mittelalters, Münstersche Mittelalter-Schriften, 66 (Munich: Fink, 1992), pp. ix-xi; Ronald G. Witt, 'The Arts of LetterWriting', in The Cambridge History of Literary Criticism, II: The Middle Ages, ed. by A. J. Minnis and Ian Johnson (Cambridge: Cambridge University Press, 2005), pp. 68-83; and Carol Poster and Richard Utz, 'A Bibliography of Medieval Latin Dictamen', in Letter-Writing Manuals and 
taught the correct execution of secretarial duties, letters soliciting appointment to that office. He would be invited to adapt a letter between a generic 'clerk' and 'bishop' to his own purposes; the letter's style and formulation would testify to the student's progress and hence support the legitimacy of his petition. ${ }^{8}$ In this context, impersonal generality was an epistolary virtue: as Charles Homer Haskins recognized, 'It was precisely because [...] they voiced the needs of the great student body everywhere and always, that these letters were considered useful to others and hence were copied and kept."

Much the same could be said of the artes dictandi themselves. From early twelfth-century Bologna, the ars dictaminis spread throughout western and central Europe, dominating Latin epistolary pedagogy and epistolary practice until at least the fourteenth century; today artes dictandi and associated materials survive in an estimated three thousand manuscripts representing hundreds of

Instruction from Antiquity to the Present: Historical and Bibliographic Studies, ed. by Carol Poster and Linda C. Mitchell, Studies in Rhetoric/Communication (Columbia: University of South Carolina Press, 2007), pp. 285-300.

${ }^{8}$ See Alain Boureau, 'The Letter-Writing Norm, a Mediaeval Invention', in Correspondence: Models of Letter-Writing from the Middle Ages to the Nineteenth Century (Princeton: Princeton University Press, 1997), p. 43. This performative dimension of medieval student letters is most often noted in connection with the ubiquitous 'begging letters', in which a student writes home, reports progress in study but depletion of funds, and asks for money. Haskins cites an exercise in topical invention, consisting of twenty-two different ways of framing a request for money ('The Life of Mediaeval Students', p. 9 n. 1); the exercise is printed in Hermann Bärwald, Das Baumgartenberger Formelbuch, Fontes rerum Austriacarum, ser. 2, 25 (Vienna: Hof- und Staatsdruckerei, 1866), pp. 455-64. The student's patron and recipient of his request is, in this case, an archdeacon; the 'begging letters' are most often addressed to parents.

${ }^{9}$ Haskins, 'The Life of Mediaeval Students', p. 35; see also Giles Constable, Letters and LetterCollections, Typologie des Sources du Moyen Âge Occidental, 17 (Turnhout: Brepols, 1976), pp. 49-50. Letter collections include occasional letters obviously fictional, but even in apparently real letters, proper names are often eliminated or reduced to initials. Constable and Haskins note the problems that this practice causes for historians. In the letter exchange between clerk and bishop, discussed in the text above, the sender and recipient are unidentified; the seneschal whom the clerk will serve is identified by the initials 'I. C.' - initials whose frequent occurrence in this formulary raises the suspicion that they are fictitious. Nevertheless, it is interesting that the clerk's letter refers to a queen's arrival in England ('Cum itaque domina regina in Angliam [...] noviter sit ventura'). If the letter is not entirely fictional, then it might be associated with the arrival of Isabella of France in London in January 1397, but very little is known about the household of Richard II's second queen: see Chris Given-Wilson, The Royal Household and the King's Affinity: Service, Politics and Finance in England, 1360-1413 (New Haven: Yale University Press, 1986), p. 93. An earlier queen is also possible. 
independent treatises. ${ }^{10}$ The link between careerist ambitions and the study of ars dictaminis is, once again, made in the formularies used to teach letter-writing. In two letters contained in the teaching materials of Thomas Sampson (of whom more later), fathers urge their sons, already studying at Oxford, to leave the arts faculty and contract with Sampson 'pur apprendre escrire et diter', a phrase that probably refers to the twin tasks of taking dictation and shaping the letter's content into the appropriate formulas. ${ }^{11}$ In one of the two letters (no. 70), the boy's father announces that a certain count has guaranteed the boy a place in his household, provided that the boy learn the correct way of keeping inventories, writing, and making payments (acompter, escrire, et rendre come appent). The second letter (no. 80) names dictamen and scriptura as the skills to be learned; the letter closes with the motivational proverb, 'sciencia modernis temporibus auro disnoscitur preualere' (in the modern age, knowledge is judged to outweigh gold). In a third letter, also from Thomas Sampson's formularies, a man writes to his brother to report that he has been made steward in a lord's household. It is all welcome news, except that, alas, he lacks the skills for the job:

Et issint suy demuraunt od lui en l'office de seneschal de soun hostiel, la son merci, tot soit
que je ne say la manere d'escriver n'acompter, quelle chose grantement me poise. Pur quoi,
treschere friere, vous prie entierement que vous voillez afforcer et mettre vostre diligence
et cure d'aprendre escriver, acompter et enditer, issint que me puissez eider d'entrere
nos espensez et escriver nos lettres, entendant que vos unques ne vailastz melx qe vous
vailereez, come j'espoir, et, si come m'est avyse, greindre volentee en avereiez que nous
puissons demurrer ensemble que demurer od nulle autre estrange.

(And thus I am residing with him [that is, with the 'tiel monseignur', or 'certain lord', mentioned in the letter's opening clauses and whose identity Sampson's students would

${ }^{10}$ For the influence of ars dictaminis on epistolary composition, see Constable, Letters and Letter-Collections, p. 35; and Witt, 'The Arts of Letter-Writing', p. 68. The estimate of surviving manuscripts is made in Worstbrock, Klaes, and Lütten, Repertorium, p. ix. See Emil Polak's census of manuscripts: Medieval and Renaissance Letter Treatises and Form Letters: A Census of Manuscripts Found in Eastern Europe and the Former U.S.S.R. (Leiden: Brill, 1993) and Medieval and Renaissance Letter Treatises and Form Letters: A Census of Manuscripts Found in Part of Western Europe, Japan, and the United States of America (Leiden: Brill, 1994).

${ }^{11}$ The letters are nos 70 and 80 in Richardson, 'Letters', pp. 407 and 415; quotation from no. 70. For discussion, see H. G. Richardson, 'Business Training in Medieval Oxford', American Historical Review, 46 (1941), 259-80 (pp. 259-60). On the process of medieval letter-writing, see Constable, Letters and Letter-Collections, pp. 42-46. For the semantic development of dictare and its derivations, see A. Ernout, 'Dictare "Dicter", Allem. Dichten', Revue des études latines, 29 (1951), 155-61.

${ }^{12}$ Richardson, 'Letters', no. 20, pp. 371-72. 
be invited to supply for themselves] by his leave, as seneschal of his household, even though I do not know how to write or keep accounts - a matter that greatly distresses me. Considering this, dearest brother, I sincerely ask you to fortify yourself and direct all your effort and care to learn writing, accounting, and composition, so that you can help me to enter our expenses and write our letters; do this, understanding that you have never profited more than you will profit here, as I expect. And in my opinion you should be even more receptive to this, since we will be able to live together rather than with nonrelations.)

Since he cannot get away to learn writing, accounting, and composition himself, he asks his brother to do so on his behalf. If the letter is not a fiction, its sender presumably would have dictated his message to a clerk who did the actual writing and composition. But there is perhaps a touch of comedy in the letter sender's desperate situation and it is more likely that Sampson composed all three of these promotional letters himself. As I will show in more detail below (pp. 306-07), Sampson provided intensive and dedicated training in skills that were equally necessary to many students of the university arts course, but which destined students to relatively low-level positions when acquired in isolation, that is, when acquired as an alternative to the university arts course. Nevertheless, the letters' felicity as statements in support of Sampson's teaching would depend upon a certain correspondence between the scenarios that they evoke and the ambitions of his clients. To Haskins's observation that letters were copied and kept because they met enduring student needs, we can add that letters may also imply the desires and expectations that students had for their training in ars dictaminis. In this essay, I explore the resources that the ars dictaminis provided to its teachers, students, and practitioners for conceiving of their social world and locating themselves within it. More generally, I am interested in the experience of those late medieval people who aspired, on the basis of their linguistic acquisitions, to serve the interests and receive the rewards of the realm's lay and ecclesiastical magnates. ${ }^{13}$

${ }^{13}$ Although my methods and materials differ from theirs, I feel a particularly close affinity with Ralph Hanna's comments on what he calls the 'dependent clerks' who constituted late medieval England's 'domestic governing class' and with Steven Justice's reflections on the work of John of Exeter, the Norwich cathedral registrar who recorded heresy trials for Bishop Alnwick between 1428 and 1431: see Ralph Hanna III, 'Lambeth Palace Library, MS 260, and the Problem of English Vernacularity', Studies in Medieval and Renaissance History, ser. 3, 5 (2008), 131-99 (p. 165); Ralph Hanna III, 'Sir Thomas Berkeley and his Patronage', Speculum, 64 (1989), 878-916 (pp. 892-94 and 913-16); and Steven Justice, 'Inquisition, Speech, and Writing: A Case from Late Medieval Norwich', in Criticism and Dissent in the Middle Ages, ed. by Rita Copeland (Cambridge: Cambridge University Press, 1996), pp. 289-322. For speculations on the class backgrounds of 
It has often been noted that the emergence and dissemination of the ars dictaminis coincided with rapid increases in the volume, social distribution, and importance of written records and practical literacy in medieval Europe. ${ }^{14}$ Perhaps unsurprisingly, expansion in the social functions and demographic distribution of written communication was accompanied in the new artes dictandi by intensified notation of the existing social hierarchy. Giles Constable has shown that the ars dictaminis developed detailed accounts of the 'structure of medieval society. ${ }^{15}$ The salutation of a letter attracted especially detailed instruction, since the precise form of address and greeting should express the status of and relations between the letter's sender and recipient. To reconstruct the experience of a social world implicated in these anatomies of the social world, it is necessary to grasp the artes

students at medieval English universities, see Evans, 'The Number, Origins, and Careers of Scholars', pp. 511-15; and Alan B. Cobban, The Medieval Universities: Their Development and Organization (London: Methuen, 1975), p. 190. For relations between literate work and the patronage system in the households of late medieval English nobility and gentry, see Hanna, 'Sir Thomas Berkeley'; and Richard Firth Green, Poets and Princepleasers: Literature and the English Court in the Late Middle Ages (Toronto: University of Toronto Press, 1980).

${ }^{14}$ Witt, 'The Arts of Letter-Writing', pp. 69-70; and Franz Josef Worstbrock, 'Die Antikerezeption in der mittelalterlichen und der humanistischen Ars dictandi, in Die Rezeption der Antike: Zum Problem der Kontinuität zwischen Mittelalter und Renaissance, ed. by August Buck, Wolfenbütteler Abhandlungen zur Renaissanceforschung, 1 (Hamburg: Hauswedell, 1981), pp. 187-88. M. T. Clanchy shows how the ars dictaminis served the needs of practical literacy at the most basic level of writing and dictation (From Memory to Written Record, England 1066-1307, 2nd edn (Oxford: Blackwell, 1993), pp. 125-26 and 271). William Patt connects the ars dictaminis to growing personnel requirements in chanceries: 'The Early Ars dictaminis as Response to a Changing Society', Viator, 9 (1978), 133-55 (pp. 146-47). Patt's conclusions that the ars dictaminis had no specifiable point of geographical origin should be read in the light of Franz Josef Worstbrock, 'Die Anfänge der mittelalterlichen Ars dictandi', Frühmittelalterliche Studien, 23 (1989), 1-42. For response to Patt's thesis, see ibid., p. 31 n. 132. A concise and synoptic statement of the relations between, on the one hand, the textual and pedagogical traditions of the ars dictaminis and, on the other, contemporary transformations in the social roles and distribution of practical literacy, is probably still beyond the reach of current scholarship: the problems encountered are both empirical (variations over time and place, unedited treatises and unstudied manuscripts) and conceptual (how does one conceive of the relationship between disciplinary practices and the social circumstances of their elaboration?).

${ }^{15}$ Giles Constable, 'The Structure of Medieval Society According to the Dictatores of the Twelfth Century', in Law, Church, and Society: Essays in Honor of Stephan Kuttner, ed. by Kenneth Pennington and Robert Somerville (Philadelphia: University of Pennsylvania Press, 1977), pp. 253-67; see also Paul Krüger, Bedeutung und Entwicklung der 'Salutatio' in den mittelalterlichen Briefstellern bis zum 14. Jahrbundert (Greifswald: Adler, 1912). 
dictandi in their fully practical orientation: as guides to the composition of documents, artes dictandi were necessarily also guides to a specific form of conduct. Guido Faba's Summa dictaminis provides a convenient illustration. ${ }^{16}$ Composed 1228-29 in Bologna, Guido's Summa dictaminis was one of the most widely copied and influential manuals of letter-writing, well represented in English collections. ${ }^{17}$ The medieval ars dictaminis typically devoted far more instruction to the letter's salutation than to its other parts; here the salutation occupies approximately a third of the treatise's total length ( $\$ 5-67)$. In this section, a notary or chancery clerk would find sample salutations suited to letters from a son to parents, between brothers, from a student to a teacher, a subordinate to a prelate, a subordinate to a lay lord, a king to the pope, the pope to an emperor, and so on. In total, Guido provides sample salutations for almost fifty different combinations of sender and recipient; the salutations are organized by rank and propinquity, first ascending through the orders of lay society, beginning with letters between family members and ending with letters between emperors ( $\$ \$ 12-41$ ), then descending through the church, beginning with the pope and ending with monks and hermits $(\$ \$ 42-57) .{ }^{18}$ Thus, social rank figures as both the content of instruction and as a textual finding device, that is, the means by which a student of ars dictaminis located epistolary forms appropriate to a given occasion. ${ }^{19}$ A clerk who wished to write to an episcopal patron would find the

${ }^{16}$ Augusto Gaudenzi, 'Guidonis Fabe, Summa dictaminis', Il Propugnatore, n.s., 3 (1890), 287-338 and 345-93; hereafter references are cited by section numbers in this edition. For commentary, see Charles Faulhaber, 'Guido Faba's Summa dictaminis', in Medieval Eloquence: Studies in the Theory and Practice of Medieval Rhetoric, ed. by James Jerome Murphy (Berkeley and Los Angeles: University of California Press, 1978), pp. 85-111.

${ }^{17}$ For manuscripts, see Polak, Medieval and Renaissance Letter Treatises and Form Letters: A Census of Manuscripts Found in Part of Western Europe; for English copies, see Camargo, Medieval Rhetorics, p. 16; and Noel Denholm-Young, Collected Papers on Mediaeval Subjects (Oxford: Blackwell, 1946), 'The Cursus in England', pp. 48-50.

18 The inventory ends with three miscellaneous entries, containing salutations for judges $(\$ 62)$, the wealthy and the avaricious $(\$ 63)$, and merchants and farmers $(\$ 64)$.

${ }^{19}$ Similarly, full letters in formularies were often titled with a short phrase indicating the status of sender and recipient (e.g., 'De clerico ad episcopum') and ordered by rank, beginning with letters to the king, emperor, and pope, then descending through the social hierarchy to letters between students and friends. On the development of medieval finding devices, see M. B. Parkes, 'The Influence of the Concepts of Ordinatio and Compilatio on the Development of the Book', in Scribes, Scripts, and Readers: Studies in the Communication, Presentation, and Dissemination of Medieval Texts (London: Hambledon, 1991), pp. 35-70; and Richard H. Rouse and Mary A. Rouse, 'Statim Invenire: Schools, Preachers, and New Attitudes to the Page', in Renaissance and 
appropriate salutations near the middle of the first section of the inventory, after a sequence of entries for letters between family members $(\$ \$ 12-25)$ and friends (\$\$ 26-27), and immediately following an entry for letters 'From students to teachers and vice versa' ( $\$ 28)$. Here, under the heading 'From a subordinate to a prelate' (\$29), our clerk would find two full and six partial salutations, which he could mix and match to build a salutation such as the following:

[1] Venerabili in Christo patri et domino $N$. Dei gratia dignissimo episcopo talis loci [2] $N$. suus clericus subditus et fidelis [3] seipsum totum, et obedientiam et reverentiam et devotionem perpetuam.

Italics above indicate names of persons and places to be supplied by the letterwriter; numbers in brackets distinguish the three main parts of the salutation: [1] the inscriptio, or 'name of the addressee, with his attributes'; [2] the intitulatio, 'sender's name, with his attributes'; and [3] the salutatio proper, or 'initial greeting. ${ }^{20}$ The inscriptio is always in the dative case, intitulatio always in the nominative, and salutatio in the accusative $(\$ 10)$. A finite governing verb such as mittit is understood, but omitted by long-standing convention $(\$ 61)$. The order in which sender and recipient are named expresses relative rank: the higherranking party should be named first $(\$ 8)$. Meanwhile, the attributes and greeting are selected to express the status of and relationship between the two parties: in this case, the clerk acknowledges the position held by his letter's addressee, identifies himself as subordinate to and dependent on his addressee, and pledges humility, deference, and obedience. ${ }^{21}$ The entry 'From a subordinate to a prelate' contains, in addition to the sample salutations already reviewed, a cross-reference to an earlier entry 'where', Guido writes, 'you will find more words that suit this situation'. Consultation of that earlier entry ('From a nephew to an uncle

Renewal in the Twelfth Century, ed. by Robert Louis Benson and Giles Constable (Cambridge, MA: Harvard University Press, 1982), pp. 201-25.

${ }^{20}$ Carol Dana Lanham, 'Salutatio' Formulas in Latin Letters to 1200: Syntax, Style, and Theory, Münchener Beiträge zur Mediävistik und Renaissance-Forschung, 22 (Munich: ArbeoGesellschaft, 1975), p. 7. Cf. Guido Faba, Summa dictaminis, $\$ 6$.

${ }^{21}$ On salutations expressing humility and deference, see Krüger, Salutatio, pp. 24-36. Attributes and laudatory epithets such as venerabilis were especially important because they were graded by rank, some more strictly than others (cf. Guido Faba, Summa dictaminis, §66). Guido also provides interesting guidance on exceptions and gray areas: cases in which the phrase in Christo' is omitted from the inscriptio ( $\$ 43)$; when, if ever, one should withhold the conventional greeting, either from humility or ill-will $(\$ \$ 8,62)$; and how to coordinate lay and ecclesiastical hierarchies $(\$ 50)$. 
in clerical orders', $\$ 18$ ) would provide our clerk with the laudatory epithet 'reuerendus' as an alternative to 'venerabilis', as well as many additional salutationes expressing suitable humility and deference. Finally, an entry in the second part of Guido's inventory would show the clerk that he could perhaps expect to be greeted, in the return letter, with the phrase 'dilecto in Cristo filio' ( $\$ 49)$; the greeting formula might be selected not by the bishop himself, but by a clerk working in the episcopal chancery. Thus, through the combination of graded laudatory epithets, greeting formulas, and the relative order of intitulatio and inscriptio, the salutation was fitted to both the absolute and relative status of sender and recipient.

The ostensible purpose of such instruction was to ensure that the letter proceeded in a manner appropriate to its circumstances and hence to maximize the sender's chances of receiving a favourable hearing. ${ }^{22}$ However, the specifically codified form taken by this instruction lent the instruction a slightly different function: by providing a menu of ready-made and approved formulas, the ars dictaminis spared chancery clerks and notaries from the task of making independent judgements concerning matters of social decorum. To appreciate the functional significance of codification, one can compare Guido Faba's instructions on the salutation with those provided in Julius Victor's Ars rhetorica (probably late fourth century), in which everything is left up to the writer's judgement: 'Salutations and subscriptions', Julius Victor writes, 'should be calibrated to degrees of friendship and rank, observing conventional norms. ${ }^{23}$ Such advice was presumably felt to be insufficient in the twelfth and thirteenth centuries, when the lay and ecclesiastical elite were increasingly relying more on people from lower classes than their own to produce the records and communications they needed to maintain their dominance. Recruited from outside of the dominant classes, the clerical labourer would be inserted into a social world for which the habitus that he owed to his family background and upbringing

22 The salutatio shared this purpose with the exordium, which was often given the name captatio benevolentie. Terminology and purpose were adapted from classical rhetoric's instruction in oration. On borrowings from classical rhetoric, especially the division of the letter, see Ronald Witt, 'Medieval Ars dictaminis and the Beginnings of Humanism: A New Construction of the Problem', Renaissance Quarterly, 35 (1982), 1-35 (pp. 8-12). On the connection between the salutatio and captatio benevolentie, see also Lanham, 'Salutatio' Formulas, pp. 93-94, 109-18.

23 'Praefationes ac subscriptiones litterarum computandae sunt pro discrimine amicitiae aut dignitatis, habita ratione consuetudinis': Julius Victor treats letter-writing in a brief appendix to his Ars rhetorica, pp. 447-48, in Rhetores Latini Minores, ed. by Karl Halm (Leipzig: Teubner, 1863), quotation at p. 448.23-25. For discussion, see Lanham, 'Salutatio' Formulas, p. 90. 
could not serve as a reliable guide. ${ }^{24}$ Simultaneously, clerical labour itself became increasingly independent of the powers that employed it and set it in motion: in chanceries, documents could be drawn up without the direct and continuous oversight of the persons in whose name they were produced. Thus, scrupulous attention to relative and absolute social rank probably registers a structural transformation in the production of written communications. Once standard letter forms were adopted by a few key chanceries — and particularly the papal court - they quickly attained an indirect obligatory force, such that even those with the rhetorical and social capacities for independent judgement felt bound to observe the same formulas. ${ }^{25}$

I have examined salutation doctrine in some detail because it allows me to formulate a methodological principle for study of the medieval letter-writing manuals: the content of the artes dictandi registers the recruitment of a domestic governing class, a class that owed its identity and privileges to the fact that literate skills were becoming increasingly necessary to the exercise of political and economic power. Towards the end of this essay, I will employ this methodological principle in an interpretation of the manuals' instructions in cursus. Before proceeding to discussion of cursus, it is necessary to develop one more methodological principle, complementary to the one I have just presented. I have attempted to show the relations between dictaminal instruction and the positions for which this instruction allegedly prepared its students. It is also necessary to grasp the ars dictaminis as one pedagogical tradition among others, that is, as a participant in a field.

${ }^{24}$ Families whose socioeconomic position permitted them to do so often sent young sons and daughters to live and serve in houses of the nobility. One of the benefits of this custom was presumably that a child learned how to conduct him- or herself around superiors. In comparison with the durably incorporated practical understanding that children would acquire through early immersion in high society, the discursive instruction provided by medieval conduct-manuals or, indeed, the ars dictaminis - surely constituted an inferior, more fragile, guide to correct conduct. The rise of the ars dictaminis as a pedagogical tradition may therefore register an expansion in written communications, beyond what could be met by individuals who owed their knowledge of social decorum to early immersion in high society. On modal differences in the learning of epistolary forms, see further below, p. 307. The implications of modal differences in the acquisition of cultural knowledge is a key problematic explored in Pierre Bourdieu's sociology: see Pierre Bourdieu and Jean Claude Passeron, Reproduction in Education, Society, and Culture, trans. by Richard Nice, 2nd edn (London: Sage, 1990).

25 Ronald Witt, 'Boncompagno and the Defense of Rhetoric', Journal of Medieval and Renaissance Studies, 16 (1986), 1-31 (pp. 20-24). 


\section{'Ars dictaminis' in the Field of Education}

The codification of written communication, stressed in the preceding section, was not unopposed. Indeed, the emergence and elaboration of the ars dictaminis was less a triumph of codified documentary culture over classicizing literary culture than the opening of a new field of contest between these opposed norms of literate pedagogy. What I mean by 'codified documentary culture' should be clear from my discussion of Guido Faba's salutation doctrine; by 'classicizing literary culture' I mean a type of medieval education in which a student approached the task of composition through extended reading of literary masterpieces, typically guided by commentary or glosses and an accessus or introductory headnote. ${ }^{26}$ From the late twelfth century to the early fifteenth century, there were periodic efforts to reintegrate the ars dictaminis into the tradition of classical rhetorical and grammatical teaching from which it had in part derived. In the second half of the twelfth century, teachers in the Loire Valley of central France infused ars dictaminis with elements of traditional literary grammar. ${ }^{27}$ By the beginning of the following century, these French developments in ars dictaminis were known in northern Italy; Italian dictatores responded by attempting, in a variety of ways, to reconnect the specific art of letter-writing with the more comprehensive traditions of classical rhetoric. ${ }^{28}$ These efforts to reconnect the ars dictaminis with the classical language arts differed from one another, but each also differed from contemporary developments in the codified and formulaic approach to written communication. ${ }^{29}$ The existence of alternative visions of dictamen - roughly,

${ }^{26}$ See A. J. Minnis and A. B. Scott, Medieval Literary Theory and Criticism, c. 1100 -c. 1375: The Commentary-Tradition (Oxford: Clarendon Press, 1988), especially Chapters 1,2, and 4; and Rita Copeland and Ineke Sluiter, Medieval Grammar and Rhetoric: Language Arts and Literary Theory, A.D. 300-1475 (Oxford: Oxford University Press, 2009), especially Parts III and IV.

${ }^{27}$ Franz Josef Worstbrock, 'Die Frühzeit der Ars Dictandi in Frankreich', in Pragmatische Schriftlichkeit im Mittelalter: Erscheinungsformen und Erwicklungsstufen, ed. by Hagen Keller, Klaus Grubmüller, and Nikolaus Staubach (Munich: Fink, 1992), 143-55.

${ }^{28}$ See W itt, 'Boncompagno', and John O. Ward, 'Rhetorical Theory and the Rise and Decline of Dictamen in the Middle Ages and Early Renaissance', Rhetorica, 19 (2001), 175-223 (pp. 190-202).

${ }^{29}$ For documentary composition in France, see Worstbrock, 'Ars dictandi in Frankreich', pp. 137-40; and Charles Vulliez, 'L'Apprentissage de la rédaction des documents diplomatiques à travers l'ars dictaminis français (et spécialement ligérien) du XII ${ }^{\mathrm{e}}$ siècle', in Cancelleria e cultura nel medio evo: Comunicazioni presentate nelle giornate di studio della Commissione; Stoccarda, 29- 30 agosto 1985, XVI Congresso internazionale discienze storice, ed. by Gualdo Germano (Vatican City: 
literary-grammatical, rhetorical, and documentary - exerted a force on each individual teacher or author of a textbook: dictatores could always distinguish their own approach from the instruction (obviously flawed) provided by their rivals. Disciplinary positioning of this type peaked among the Italians of the early thirteenth century, perhaps most notably in the works of Boncompagno da Signa and in Guido Faba's prologues. Boncompagno denounced the school of Orléans for encouraging literary excesses in epistolary prose and denounced his Italian rivals for following the French lead. Guido Faba prefaced his Rota nova with an elaborately coded narrative in which he distinguished his practice from both courtroom pleading and the paralegal composition of notaries, presenting himself as dedicatee and exponent of the 'literary dimension of dictamen'. ${ }^{30}$ The fact that Guido's manuals continued to take a highly formulaic and codified approach to key parts of the letter - as we saw in the previous section - shows that his preface is the product of a discursive environment that has achieved a high level of disciplinary uniformity: small differences of approach and emphasis could become charged with disproportionate significance. Moreover, Guido's act of taking a position relative to other, alternative, approaches to ars dictaminis depends for its intelligibility on the existence of a collectively acknowledged norm, namely, the superiority of integral literary study to instrumental literacy. In Pierre Bourdieu's sociology of culture, which I am here employing, the term field names a virtual space within which cultural actors locate themselves relationally and give normative meaning to the differences between their own practice and that of others. ${ }^{31} \mathrm{~A}$ field is virtual because, rather than corresponding directly

Archivio Segreto Vaticano, 1990), pp. 77-95. In Italy the key developments were the ars notaria and tabular artes dictandi: Peter Weimar, 'Ars notariae', in Lexikon des Mittelalters, 10 vols (Munich: Artemis; Munich: Lexma; Stuttgart: Metzler, 1977-98), I, cols 1045-47 (also available at Brepolis Medieval Encyclopaedias Online, Lexikon des Mittelalters Online, <http://www. brepols.net/Pages/BrowseBySeries.aspx?TreeSeries=LEXMA-O); and James Jerome Murphy, Rhetoric in the Middle Ages: A History of Rhetorical Theory from Saint Augustine to the Renaissance (Berkeley and Los Angeles: University of California Press, 1974), pp. 258-63 (on Lawrence of Aquilegia's tabular ars dictaminis).

${ }^{30}$ Rita Copeland, 'Medieval Intellectual Biography: The Case of Guido Faba', in Through a Classical Eye: Transcultural and Transhistorical Visions in Medieval English, Italian and Latin Literature in Honour of Winthrop Wetherbee, ed. by Andrew Galloway and Robert F. Yeager (Toronto: University of Toronto Press, 2009), pp. 109-24 (p. 116).

${ }^{31}$ For Bourdieu's field theory, see Pierre Bourdieu, The Rules of Art: Genesis and Structure of the Literary Field, trans. by Susan Emanuel (Stanford: Stanford University Press, 1996), pp. 18184, 199-200, 214-77; and Pierre Bourdieu, Pascalian Meditations, trans. by Richard Nice 
to a geographical or political unit, to a genre or a medium, its dimensions are drawn by the motivated and normative visions that cultural actors have of one another. Acts of position-taking such as that of Guido Faba depend, for their intelligibility, on their implication within a normatively distributed collective, or field. Reciprocally, fields are continuously generated by the individuals and institutions who appeal to norms in order to meaningfully locate themselves and distinguish their practice within a collective. One result of this reciprocity is that fields, while virtual, inscribe themselves into the individual cultural works produced within them: cultural works acquire irreducibly relational qualities, qualities that only make sense as efforts to stake out a position within a normatively distributed collective. Here, then, is a second methodological principle for study of ars dictaminis: some features of the manuals may be explained by indexing the manuals to their position within a cultural field.

During the second half of the fourteenth century, an internally differentiated teaching tradition of ars dictaminis developed in England, comparable to that observed in the French and Italian traditions, if on a considerably smaller scale. ${ }^{32}$ One group of teachers attempted a rapprochement with the tradition of classical rhetoric, producing manuals of ars dictaminis that drew heavily on twelfthcentury arts of poetry and prose; another group stripped ars dictaminis to its formulaic essentials and taught letter-writing alongside the basic administrative skills of accounting and the drafting of legal instruments. These differences of approach could have important consequences for the teachers' self-presentation, as I will show in the third section, below. In assessing the position of ars dictaminis within an English field of education, the most important factor is probably institutional affiliation. Both the literary and documentary strands of ars dictaminis were centred at Oxford, but neither was adopted into statutory

(Stanford: Stanford University Press, 2000), pp. 93-127. For the language of norms, see Robert B. Brandom, 'Some Pragmatist Themes in Hegel's Idealism: Negotiation and Administration in Hegel's Account of the Structure and Content of Conceptual Norms', European Journal of Philosophy, 7 (1999), 164-89.

${ }^{32}$ Camargo, Medieval Rhetorics, pp. 1-34. For the influence of ars dictaminis on documentary and epistolary practice in England, see Denholm-Young, 'Cursus in England'. Because much of Denholm-Young's essay is devoted to the royal chancery, brief yet important remarks about private correspondence and routine legal documents (see pp. 40-41) went largely unnoticed in subsequent scholarship. For detailed elaboration of Denholm-Young's remarks and an assessment of the influence of ars dictaminis on Latin letters of late medieval England, see Charles Everitt, 'Eloquence as Profession and Art: The Use of the Ars dictaminis in the Letters of Gilbert Stone and his Contemporaries, 1300-c.1450' (unpublished doctoral dissertation, Oxford University, 1985). 
curricula. ${ }^{33}$ Nor, with some exceptions, was ars dictaminis taught in English grammar schools. ${ }^{34}$ To see how this double exclusion - from grammar schools and from the university faculties - shaped dictamen's status and participation within English literate culture, it is necessary to take a slightly wider perspective, that is, to reconstruct the normatively structured space within which ars dictaminis was taught and studied.

The loquacious opposition between ecclesiastical and professional norms probably constituted an important dimension of the educational field of later medieval England. A young man at university asks his uncle to heal a familial dispute over the direction of his studies. The man's father wants him to study civil law, on the principle that 'qui causas scit discernere ciuiles, pecuniaria substancia non carebit' (a lawyer will never lack a sufficient income). Meanwhile, the student wishes to study arts in preparation for an ecclesiastical career, on the principle that 'huius vite perfecte viaticus lucra temporalia respuere debet et celestibus adherere' (a soul journeying in the true life ought to renounce earthly wealth and cling

${ }^{33}$ This bifurcated tradition of non-statutory dictaminal instruction may be compared with the institutional situation of ars dictaminis in fourteenth-century Bologna, where the commune provided for university masters to lecture on both dictamen and the Rhetorica ad Herennium. Lectures were delivered by a single master, but at different locations within the city and addressed to different kinds of student: 'The lectures on the dictamen text were practical, brief, and directed to men of the notarial guild, while lectures on the classical rhetorical text were directed in the University to students who were committed to a lengthy period of study' (James R. Banker, 'The Ars dictaminis and Rhetorical Textbooks at the Bolognese University in the Fourteenth Century', Medievalia et humanistica, n.s., 5 (1974), 153-68 (p. 157)). See also Martin Camargo, 'Between Grammar and Rhetoric: Composition Teaching at Oxford and Bologna in the Late Middle Ages', in Rhetoric and Pedagogy: Its History, Philosophy, and Practice: Essays in Honor ofJames J. Murphy, ed. by Winifred Bryan Horner and Michael C. Leff (Hillsdale, NJ: Erlbaum, 1995), pp. 89-91.

${ }^{34}$ Martin Camargo, 'If You Can't Join Them, Beat Them; or, When Grammar Met Business Writing (in Fifteenth-Century Oxford)', in Letter-Writing Manuals and Instruction from Antiquity to the Present, ed. by Poster and Mitchell, pp. 67-87 (p. 68 and n. 3). There were exceptions. The school at St Albans examined its students in composition of model letters: Nicholas Orme, Medieval Schools: From Roman Britain to Renaissance England (New Haven: Yale University Press, 2006), p. 152. See also the 'Summary Index to the Manuscript Contents', s.v. 'Dictamen', in David Thomson, A Descriptive Catalogue of Middle English Grammatical Texts (New York: Garland, 1979). In a forthcoming essay, Traugott Lawler shows how a grammar-school student might have learned to compose Latin quantitative verse using a collection of mostly Latin proverbs in Manchester, John Rylands Library, MS Latin 394. The only other major item in this manuscript, written in the same hand, is Simon O.'s Summa dictaminis (on which, see the third section, 'Partiality and the Presentation of Cursus', below). The Latin proverbs would also have provided material for the exordia of letters. 
to the heavenly)..$^{35}$ In formulations such as this, the opposition between the secularius denarius and the divinum talentum was transposed into education. At one pole of the field, independent teachers at Oxford and the communal houses of lawyers and law clerks in London provided instruction that agreed closely with the professional demands of business, law, and estates administration. At the opposite pole, the university theology faculties, the cathedral schools, and the schools of the religious orders provided training closely responsive to the church's mission of fostering Christian orthodoxy and orthopraxis. Of course, educational practices also differed from one another with respect to their social visibility and institutional organization. The universities and the studia of the friars were far more visibly successful, far more prestigious and organized, than the cathedral schools and business teachers. ${ }^{36}$ Likewise, monks could evoke their perceived inferiority to the learned friars as an additional motivation for new educational initiatives. ${ }^{37}$ Very schematically, then, the field of education could be said to be structured in two normative dimensions: in a first dimension, educational practices differed in principle; in a second dimension, they differed in their ability to make themselves recognized as legitimate incarnations of their specific principle. Within this normatively structured space, the universities introduced several interesting complications. The orders of regular clergy recognized the universities as preeminent centres of study, went to considerable lengths to provide university training to their members, and sought to have their own programmes of study recognized by the universities. ${ }^{38}$ Yet the success of the

${ }^{35}$ Richardson, 'Letters', no. 96.

${ }^{36}$ For the provision of teaching at English secular cathedrals and the eclipse of cathedral schools by the universities and mendicant studia in the thirteenth and fourteenth centuries, see Kathleen Edwards, The English Secular Cathedrals in the Middle Ages: A Constitutional Study with Special Reference to the Fourteenth Century, 2nd edn (Manchester: Manchester University Press, 1967), pp. 185-205. After the rise of the universities, the English cathedral schools provided advanced training in theology to local clergy who may lack the time, resources, or ability for university study: Orme, Medieval Schools, pp. 80-83; and Nicholas Orme, Education in the West of England, 1066-1548: Cornwall, Devon, Dorset, Gloucestershire, Somerset, Wiltshire (Exeter: University of Exeter, 1976), p. 23.

${ }^{37}$ M. W. Sheehan, 'The Religious Orders, 1220-1370', in The History of the University of Oxford, I: The Early Oxford Schools, ed. by J. I. Catto (Oxford: Clarendon Press, 1984), pp. 213-15, 220; Orme, Medieval Schools, p. 267.

${ }^{38}$ Courtenay, Schools and Scholars, pp. 56-87; Sheehan, 'The Religious Orders', pp. 193-221; and R. B. Dobson, 'The Religious Orders, 1370-1540', in The History of the University of Oxford, II: Late Medieval Oxford, ed. by Catto and Evans, pp. 539-79. 
universities was complicated by the fact that, as they emerged into a position of preeminence during the thirteenth century, they developed independent norms of educational practice, norms that derived from their own institutional procedures and acquired an authority increasingly differentiated from the norms of both professional and ecclesiastical training. From the thirteenth century through the fifteenth, university teachers' guilds strove to establish themselves as selfgoverning entities, independent of episcopal authorities. ${ }^{39}$ Reciprocally, the interventions of episcopal authorities, the mendicant orders, and ecclesiastical college benefactors each - despite differences in strategy and motivation - attempted to realign the university's productive organization with ecclesiastical norms. At the professional pole, the key feature in the field's configuration was the absence of important traditions of professional training from the university faculties. Canon and civil law were taught, but the absence of common law from the university faculties created a structural disagreement between university teaching and the legal practice of English secular courts. ${ }^{40}$ Responding to this structural disagreement, the Inns of Chancery and Inns of Court - centres for study of common law in London - increased in prominence and organization over the course of the fifteenth century. By the end of the century, these institutions approached the universities in formality of instruction, architectural form, and communal living arrangements. ${ }^{41}$

Within this normatively structured space, instruction in ars dictaminis occurred in several subordinate positions, with consequences for both its status and function. In the first instance, the exclusion of professional training from the university faculties probably enabled teachers of ars dictaminis to achieve an importance that was incommensurate with their numbers. From the early thirteenth century until around 1470 , a small number of freelance teachers at Oxford provided practical training in the literate skills needed for estates administration

${ }^{39}$ See Alan B. Cobban, The Medieval English Universities: Oxford and Cambridge to c. 1500 (Berkeley and Los Angeles: University of California Press, 1988), pp. 274-99.

${ }^{40}$ The university at Bologna, where legal studies predominated, shows the extent to which, in different circumstances, the university-form could maintain a heteronomous orientation, closely responsive to the extrinsic demands of law and commerce. See Cobban, The Medieval Universities, pp. 48-74, 170-77. Evans discusses the careers of graduates in civil and canon law ('The Number, Origins, and Careers of Scholars', pp. 528-31).

${ }^{41}$ Paul Brand, 'Courtroom and Schoolroom: The Education of Lawyers in England Prior to 1400', Historical Research, 60 (1987), 147-65; and Evans, 'The Number, Origins, and Careers of Scholars', p. 521. 
and professional correspondence. ${ }^{42}$ The teachers of business were not part of the university guild and, if surviving records can be trusted, there was no similar teaching available in medieval Cambridge. ${ }^{43}$ The aims of this curriculum are clearly stated in the teaching materials of Thomas Sampson, whose exceptionally long career ( $f$ l. late 1360s? -1409 or later) and prolific composition of textbooks make him the central figure among the business teachers. One of Sampson's textbooks on conveyancing describes itself as 'designed to instruct boys who seek positions in the service of lords, magnates, and other important men, making them better qualified for and more capable of service to their lords - and even brokers, God willing. ${ }^{44}$ In addition to conveyancing and letter-writing, the business course taught French grammar, common-law pleading, accountancy, and perhaps even heraldry. Teaching materials were in French and Latin, reflecting the use of both languages in contemporary domains of law, commerce, and estates management. ${ }^{45}$ Several surviving formularies present letters in paired Latin and

${ }^{42}$ On 'business training' in Oxford, see especially the following studies by H. G. Richardson: 'Letters'; 'Business Training'; 'An Oxford Teacher of the Fifteenth Century', Bulletin of the John Rylands University Library of Manchester, 23 (1939), 436-57; 'The Oxford Law School Under John', Law Quarterly Review, 57 (1941), 319-38. See also Evans, 'The Number, Origins, and Careers of Scholars', pp. 523-26; and Camargo, 'If You Can't Join Them, Beat Them'. For indication of the subjects taught, see Richardson's census of treatises ascribed to or associated with Thomas Sampson: 'Business Training', pp. 276-80.

${ }^{43}$ Cobban, The Medieval English Universities, p. 348; cf. Orme, Medieval Schools, p. 72.

44 'Cartuarium bonum factum pro informatione iuuenum in seruiciis dominorum et magnatum ac aliorum venerabilium virorum commorari intendencium, vt ad seruicia dominorum suorum accerciores et habiliores reddantur et, omnipotentis Dei gracia, promotores': qtd. in Richardson, 'Letters', p. $336 \mathrm{n}$. 1. The word promotor occurs in period business and legal contexts meaning 'one who advances or furthers an affair or business' and 'one who prosecutes a case': see the Dictionary of Medieval Latin from British Sources and also the Anglo-Norman Dictionary (s.v. 'promoteur').

${ }^{45}$ For the business teacher's French materials, see Rothwell, 'Stratford Atte Bowe', pp. 192-95; M. Dominica Legge, 'William of Kingsmill: A Fifteenth-Century Teacher of French in Oxford', in Studies in French Language and Mediaeval Literature, Presented to Professor Mildred K. Pope (Manchester: Manchester University Press, 1939), pp. 241-46; and Douglas A. Kibbee, 'For to Speke Frenche Trewely': The French Language in England, 1000-1600: Its Status, Description, and Instruction (Amsterdam: Benjamins, 1991), pp. 74-85. For the languages of record in the domains of law and commerce, see Clanchy, From Memory to Written Record, pp. 197-223; Paul Brand, 'The Languages of the Law in Later Medieval England', in Multilingualism in Later Medieval Britain, ed. by D. A. Trotter (Cambridge: Brewer, 2000), pp. 63-76; Laura Wright, 'Bills, Accounts, Inventories: Everyday Trilingual Activities in the Business World of Later Medieval England', ibid., pp. 149-56; and William Rothwell, 'English and French in England After 1362', English Studies, 82 (2001), 539-59. 
French versions. Since business training was not part of statutory university study and since the business teachers must have provided instruction to only a small fraction of students who acquired positions with administrative duties, it is worth considering how a university arts student might have learned the appropriate formulas for a letter or deed. First, it is surely the case that a student with university-level training could learn the technicalities of letter-writing informally and as needed, by consulting a textbook of letter-writing or the registers and formularies assembled for this purpose at episcopal chanceries and monastic houses. Moreover, the practicalities of university life would provide a regent master or student in the higher faculties with a range of occasions to develop a working knowledge of administrative forms: fellows of endowed colleges, principals of halls and hostels, and officers of the university would gain a working knowledge of accounting, legal procedures, and epistolary formulas in the course of performing administrative duties. ${ }^{46}$ Thus, very schematically, one can identify two modes of acquiring administrative skills: there was a dedicated course of study, perhaps lasting only about six months; ${ }^{47}$ and there was the possibility of acquiring many of the same skills casually, independently, and as needed, over the course of a decade or more, while pursuing a university degree with no ostensible connection to administration. Significantly, the first mode of acquisition - the dedicated course - would lead to a lower rung of the social hierarchy than students might hope for from study in the university faculties. T. A. R. Evans writes that the business teachers 'prepared their pupils for work as clerks at a very modest level', perhaps as 'a local jobbing clerk who might combine work for manorial officers with miscellaneous tasks for other local clients, conceivably in conjunction with some non-clerical occupation' ${ }^{48}$ Earlier in this essay I examined several letters in which the sender urges or directs the addressee to learn writing, composition, and accounting from Thomas Sampson. Given the probability that students of the business course were, on average, destined to a lower final socioeconomic position than students of the university faculties, it is significant that Sampson's letters describe offers of patronage that have arisen unexpectedly and require immediate reply. The letters suggest that some students who went to university without a patron might exchange the possibility of a high-level position for a less desirable but more certain position if and when the opportunity arose.

${ }^{46}$ Cobban, English University Life, pp. 82-83; also Cobban, The Medieval English Universities, pp. 64-90 and 159.

${ }^{47}$ For this estimate, see Letter no. 21 in Richardson, 'Letters', p. 372.

${ }^{48}$ Evans, 'The Number, Origins, and Careers of Scholars', p. 526. 
If the business course presented itself as a direct transition to professional employment, there was a second tradition of English ars dictaminis that had roughly the opposite function. Whereas the artes dictandi of the business course typically dispense with all but a skeleton of theoretical instruction, preferring to teach by collections of model letters, the treatises in this second branch, exemplified by Thomas Merke's Formula moderni et usitati dictaminis, are resolutely focused on theoretical instruction in literary style. ${ }^{49}$ Merke's treatise includes just one complete model letter, but an unusually extensive discussion of the rhetorical style involved in narratio, drawing for this purpose on Geoffrey de Vinsauf s manuals. Martin Camargo has shown that, early in the fifteenth century, scribes at Oxford were copying Merke's Formula in combination with a selection of other rhetorical and literary materials to produce what seem to have been readers in prose style..$^{50}$ The rhetorical component of these readers consisted of a mix of recently compiled treatises and twelfth-and thirteenth-century 'arts of poetry and prose', especially Geoffrey de Vinsaufs Poetria nova. ${ }^{51}$ The literary component was provided by four medieval literary works: Alain de Lille's De planctu naturae, Jean de Limoges's Morale somnium Pharaonis, Guido de Columnis's Historia destructionis Troiae, and Richard de Bury's Philobiblon. 'While the four texts never constituted a reader in the narrower sense of the Libri Catoniani', Camargo writes, 'it is highly probable that they clustered together as a set of models from which two or three might be chosen to accompany one or more treatises on prose composition and, optionally, treatises on verse composition as

${ }^{49}$ On the literary strand of ars dictaminis in late medieval Oxford, see Camargo, Medieval Rhetorics, pp. 24-30, and the following additional studies: Camargo, 'Beyond the Libri Catoniani: Models of Latin Prose Style at Oxford University ca. 1400', Mediaeval Studies, 56 (1994), 16587; and Camargo, 'Tria sunt: The Long and the Short of Geoffrey of Vinsauf's Documentum de modo et arte dictandi et versificandi', Speculum, 74 (1999), 935-55. Merke's treatise is edited, with discussion of manuscripts and text, in Camargo, Medieval Rhetorics, pp. 103-47; hereafter references to this treatise are cited by line number from this edition.

${ }^{50}$ Camargo, 'Beyond the Libri Catoniani'.

${ }^{51}$ Camargo, 'Beyond the Libri Catoniani', p. 169. Among the recentiores are Merke's Formula, the Tria sunt, a treatise on colores by Simon Alcock, and an anonymous composite treatise beginning Cum inter iocunda. Martin Camargo is preparing an edition of Tria sunt, which has until now been considered an expanded version of Geoffrey de Vinsaufs Documentum de modo et arte dictandi et versificandi: see now his contributions to Copeland and Sluiter, Medieval Grammar and Rhetoric, pp. 670-81; and Geoffrey of Vinsauf, Poetria nova, trans. by Margaret F. Nims, rev. edn (Toronto: Pontifical Institute of Mediaeval Studies, 2010), p. 9. For the treatise Cum inter iocunda, see the section 'Partiality and the Presentation of Cursus', below. 
well. ${ }^{52}$ Many of the 'Oxford Readers' also contain theological, legal, and medical materials, contents that imply ownership by university students. While it has not been possible to determine with certainty how and where the Oxford Readers were used - the core rhetorical and literary contents do not correspond to any of the programmes of study recorded in the university statutes - the university grammar schools and Benedictine houses in Oxford have seemed to be the two most likely institutional locations. ${ }^{53}$ Knowledge of the medieval grammar schools in Oxford derives primarily from the statutes in which the university guild asserted its right to license, oversee, and collect fees from the teachers of grammar. ${ }^{54}$ The statutes require teachers to provide instruction in Latin verse and letters (literas), while prospective teachers were to be examined 'in the manner of composing verse and prose' (de modo versificandi et dictandi). ${ }^{55}$ Grammar schools elsewhere in medieval England did not typically teach ars dictaminis (see n. 34, above), but Oxford was a likely exception, given that the university drew a large concentration of boys with varying degrees of preparation for university study. If the town grammar schools enrolled boys who intended to study in the university faculties but required additional language training, then the Oxford Readers would have been suitable teaching instruments for this purpose. ${ }^{56}$

52 Camargo, 'Beyond the Libri Catoniani', p. 182.

${ }^{53}$ It is also possible that the Oxford Readers were not taught as such, but instead served as reference manuals: Camargo, 'Beyond the Libri Catoniani', p. 185. Compare Marianne Briscoe's query regarding teaching of the ars praedicandi: 'How Was the Ars praedicandi Taught in England?', in The Uses of Manuscripts in Literary Studies: Essays in Memory of Judson Boyce Allen, ed. by Charlotte Cook Morse, Penelope Reed Doob, and Marjorie Curry Woods (Kalamazoo: Medieval Institute Publications, 1992), pp. 41-58.

${ }^{54}$ The statutes exist in two versions, dated 'before 1313' and 'before 1380', and printed in Statuta antiqua universitatis oxoniensis, ed. by Strickland Gibson (Oxford: Clarendon Press, 1931), pp. 20-23 and 169-74, respectively. Much about the university grammar schools remains obscure: the curriculum, the age and trajectory of students, and the status of teachers. See the following studies: R. W. Hunt, 'Oxford Grammar Masters in the Middle Ages', in The History of Grammar in the Middle Ages: Collected Papers, ed. by G. L. Bursill-Hall, Studies in the History of Linguistics, 5 (Philadelphia: Benjamins, 1980), pp. 167-97 (pp. 189-91); David Thomson, 'The Oxford Grammar Masters Revisited', Mediaeval Studies, 45 (1983), 298-310; Damian Riehl Leader, 'Grammar in Late-Medieval Oxford and Cambridge', History of Education, 12 (1983), 9-14; and Camargo, 'If You Can't Join Them, Beat Them', pp. 67-69.

55 Statuta antiqua universitatis oxoniensis, ed. by Gibson, pp. 171 and 169.

${ }^{56}$ See Camargo, 'If You Can't Join Them, Beat Them', pp. 68 and 73-74; and (with reservations) 'Beyond the Libri Catoniani', pp. 182-83. 
Alternatively, the literary artes dictandi and associated texts may have been used for non-statutory teaching within Oxford's colleges and halls. Medieval colleges began their lives as endowed communal residences for students of the higher faculties; at English universities, colleges would not become primary providers of undergraduate teaching until the mid-sixteenth century. However, Alan Cobban's survey of 'decentralized teaching' in the medieval English universities reveals that a number of Oxford colleges and halls were already providing undergraduate instruction, including instruction in grammar, in the final decades of the fourteenth century. ${ }^{57}$ The monastic colleges at Oxford were among the earliest to provide such teaching; moreover, there are strong and pervasive links between the Benedictine monks and study of literary rhetoric during precisely this period. ${ }^{58}$ The houses of Benedictine monks at Oxford were part of an educational reform initiative, articulated in 1277 by a meeting of the order's English chapter and reinforced by Pope Benedict XII in 1335-39. Each provincial house was to send one of its members to a university; larger houses were to provide university training to one member in twenty. The initiative was only imperfectly implemented; nevertheless, monks became an increasingly significant contingent of the student population at Oxford over the course of the fourteenth century. Most importantly, the arrival of monks in the university town almost certainly expanded the types of teaching available there. Like the friars, monks were typically sent to the university to study theology (some studied canon law instead). Secular students who studied theology usually did so only after studying arts and determining as MA's, a course of study not permitted by the orders of regular clergy. By the late fourteenth century, the university routinely granted graces permitting regular clergy to incept in the higher faculties without an MA, provided that they had completed a period of training deemed equivalent to the arts course. Mendicants, who pioneered this exemption, were also better able to provide the expected training to their members in their order's sophisticated

${ }^{57}$ Cobban, The Medieval English Universities, pp. 174-208.

${ }^{58}$ Martin Camargo, 'Rhetoricians in Black: Benedictine Monks and Rhetorical Revival in Medieval Oxford', in New Chapters in the History of Rhetoric, ed. by Laurent Pernot, International Studies in the History of Rhetoric, 1 (Leiden: Brill, 2009), pp. 375-84; and James G. Clark, A Monastic Renaissance at St Albans: Thomas Walsingham and his Circle, c. 1350-1440 (Oxford: Clarendon Press, 2004). On the Benedictine houses at Oxford, see Courtenay, Schools and Scholars, pp. 77-80; Sheehan, 'The Religious Orders', pp. 213-18; and David Knowles, The Religious Orders in England, 3 vols (Cambridge: Cambridge University Press, 1948-55), I, 9-27 and II, 14-24. 
network of regional studia. Some of the larger monastic houses also ran lectures in philosophy and logic, but it seems that monk-students would often require additional training upon arrival at Oxford. In a set of statutes probably dating from 1363, the provincial chapter of the English Benedictine monks made provisions for lectures and disputations in philosophy, to be organized at Gloucester College, the main Benedictine house at Oxford, for the benefit of members of the order who had been sent to study at the university. ${ }^{59}$ As a substitute for the university arts course, teaching at Gloucester College should have been weighted towards logic rather than literary rhetoric; accordingly, dictamen is not named in the statutes concerning the order's Oxford venture. However, monks are known to have engaged in studies not recorded in their order's statutes, notably business training. Business teachers included monastic letters in their treatises; ${ }^{60}$ reciprocally, monasteries acquired artes dictandi and formularies of the business course, sometimes combining these materials with collections of letters written by their own houses. ${ }^{61}$ From the business teachers and their textbooks, monks would acquire the administrative skills necessary to the maintenance of their house's properties and privileges. Given the evidence of authorship, book production, and book ownership — assembled by Martin

${ }^{59}$ Documents Illustrating the Activities of the General and Provincial Chapters of the English Black Monks, 1215-1540, ed. by W. A. Pantin (London: Offices of the Royal Historical Society, 1931), II, 75-76. The statute makes the following provisions: 'If any of the students of our order is competent to lecture on philosophy but cannot yet proceed to study of theology because he has not yet completed the mandatory period of study in philosophy, then the prior of students should arrange for this student to lecture on philosophy in a suitable place; the prior of students should convene the other students of philosophy in our order, so that they receive their training in philosophy from this student.' The statute then stipulates a regimen of disputations and sermons for three different kinds of student-monk: those studying theology, those still studying philosophy, and those who are not on a track to study theology in the university faculty. Students in the last group have, the statute explains, been sent to Oxford only in order to learn from others there how to preach the word of God correctly'. This 1363 statute perhaps represents an expansion in perceived teaching needs at Gloucester College; in an earlier set of statutes, the chapter's primary concern was to provide teaching in theology: see Documents, ed. by Pantin, II, 55-56. See also Knowles, The Religious Orders in England, II, 23-24.

${ }^{60}$ For examples, see Richardson, 'Letters', nos 13, 16, 39, 40, 43, 44, 75; and Pantin, 'A Medieval Treatise on Letter-Writing', nos 27, 28, 35.

${ }^{61}$ Richardson, 'Business Training', p. 270; and Clark, Monastic Renaissance, pp. 59 and 214 n. 22. Polak, Medieval and Renaissance Letter Treatises and Form Letters: A Census of Manuscripts Found in Part of Western Europe, notes manuscripts with materials that imply monastic ownership. 
Camargo and James Clark — it seems likely that monks at Oxford also studied the literary version of ars dictaminis. In this context, a register of Durham cathedral dating c. 1400 provides a suggestive piece of evidence. In a sequence of letters between the Benedictine house at Durham and members of the house currently studying at Oxford, one finds a request for 'quodam libro qui vocatur Bellum Troianum'; the writer goes on to explain that 'a simple dictator would benefit greatly from use of such a book, which is full of stylistic refinement and verbal elegance, most succinct in its phrasing, and extremely inventive of perfect meanings' ${ }^{62}$ It is tempting to identify the requested book as the Historia destructionis Troie of Guido de Columnis, one of the four literary works that occur with Merke's Formula and other rhetorical materials in the Oxford Reader. While the title Bellum Troianum could refer to any medieval Troy-story, De bello Troiano is Thomas Merke's name for Guido's history when, in the Formula moderni et usitati dictaminis, he refers readers to this work for illustrations of the figures exclamacio and descripcio.$^{63}$ Here, then, we may have record of a student monk in Oxford, learning dictamen and seeking to assemble a reader of the type described by Camargo.

In summary, evidence indicates that teaching of ars dictaminis in late medieval Oxford served populations drawn to the town by the university, but whose needs were not fully met by the university faculties. One branch of the English ars dictaminis provided students with training in literary composition, preparatory to or concurrent with study in the university faculties. A second branch provided business training, largely to students who aimed to join manorial households as administrative servants, but also to members of the monastic orders. Benedictine monks evidently studied both branches of dictamen, pursuing a curriculum that aimed at once at university recognition, literary production, and their administrative needs.

62 '[Q] uantum simplici dictatori talis libri prodesset inspeccio, cum sit plenus stilorum elegancia, verborum facundia, clausularum compendiosus, sensuumque perfectorum totaliter invectivus [sic]': Pantin, 'Letters from Durham Registers, c. 1360-1390', in Formularies Which Bear on the History of Oxford, ed. by Salter, Pantin, and Richardson, I, 217-45 (p. 238).

${ }^{63}$ Lines 387-89 and 475-77. W. A. Pantin speculated that the title Bellum Troianum in the Durham letter probably referred to Joseph of Exeter's Troy epic, for which see Richard Sharpe, A Handlist of the Latin Writers of Great Britain and Ireland before 1540, Publications of the Journal of Medieval Latin, 1 (Turnhout: Brepols, 1997), no. 995. While Merke cites Guido de Columnis by name, the corresponding passage in Merke's source quotes an unidentified Troy poem. See notes to ll. 387-89 and also discussion in Camargo, 'Beyond the Libri Catoniani', p. 177. 


\section{Partiality and the Presentation of 'Cursus'}

I began this essay by proposing that the salutation doctrine provided by the ars dictaminis registers a structural transformation in the production of written communications: individuals from outside of the lay and ecclesiastical elite were recruited into positions where they produced, often semi-independently, the documents necessary to the maintenance of their patrons' political and economic position. In the previous section, I shifted my attention to the position and function of ars dictaminis within a field of pedagogical practices: excluded from the dominant regions of the field of higher education, the ars dictaminis functioned as a means of advancement, both within the educational field and outside of it. In the present section, I combine these two approaches, with the aim of saying something more about the experience of clerks who studied, taught, and practiced ars dictaminis. For this purpose, I turn to the manuals' instruction in cursus, a form of accentual prose rhythm commonly taught by the ars dictaminis. ${ }^{64}$ While salutation doctrine was constrained by the necessity of maintaining a representational relationship with the social world, rhythm could become a nonrepresentational index of the forces exerted by that world on literate practice. Instruction in cursus therefore provides an occasion to examine how Latin style responded to the forces of social distinction, clerical careerism, and university education in later medieval England.

For purposes of initial illustration, I turn to the Libellus de arte dictandi rhetorice, a manual composed well before the period I have been discussing. This manual was probably composed by Peter of Blois during a visit to France in 1182-83, although its manuscript circulation was English. Here is how it begins its account of cursus:

${ }^{64}$ The essay in which Noël Valois introduced the cursus to modern scholarship provides a review of medieval teaching on the subject and explanation of how the cursus worked: 'Étude sur le rythme des bulles pontificales', Bibliothèque de l'École des Chartes, 42 (1881), 161-98, 257-72. Tore Janson prints the major didactic texts on cursus, offers an account of the theory's development, and makes studies of prose rhythm in writers from the centuries on either side of the earliest surviving instructions in cursus (Prose Rhythm in Medieval Latin from the 9 th to the 13th Century, Studia latina Stockholmiensia, 20 (Stockholm: Almqvist \& Wiksell, 1975)). Ronald Witt proposes corrections to Janson's account and raises important questions about both the teaching tradition and the practice of the cursus: 'On Bene of Florence's Conception of French and Roman Cursus', Rhetorica, 3 (1985), 77-98. Janson and Witt also provide references to numerous further studies. 
Huiusmodi distinctionum fines vocant notarii Romane curie cadencias quas, velut sanctuaria celantes, nulli volunt penitus reuelare. Per illas etenim suas literas ab adulterinis discernunt. $^{65}$

(The notaries of the Roman Curia call clause endings of this type 'cadences'. As though concealing a secret shrine, they refuse to reveal these clause endings in full to anyone. And indeed, they use these clause endings to distinguish their own letters from forgeries.)

Instructions on rhythmical patterning at the beginning, middle, and end of clauses follow. Thus, the treatise would have us believe that we are being let in on the secret, almost sacred, authenticating signature used by papal notaries. Peter's claim that he teaches the rhythmical practice of the papal chancery receives support from another, very closely related, set of instructions in cursus, recorded in Paris, Bibliothèque nationale, MS lat. 2820, a manuscript written in France in the early thirteenth century. ${ }^{66}$ This second set of instructions is attributed in the manuscript to Albert de Morra, papal chancellor from 1178 to 1187 and later Pope Gregory VIII. Unfortunately, a third witness - Bene da Firenze - contradicts the first two, attributing to the French school of dictamen what these writers in France had attributed to the papal chancery. It should be possible to resolve this case of conflicting authorities by comparing the disputed cursus instructions with the rhythmical practice of contemporary papal documents. Thus, Ronald Witt finds that the beginning of Albert de Morra's chancellorship coincides with a 'dramatic tightening up' in the rhythmical practice of papal documents; after 1178, papal documents correspond closely to the rules transmitted by Peter of Blois and attributed to Albert de Morra in the Paris manuscript. ${ }^{67}$ Yet, if Peter's claim is accurate, it nevertheless remains exorbitant; it is necessary to distinguish the accuracy of his statement from its attendant force. At one level, by promising to teach readers how to reproduce the signs of authenticity, the Libellus crystal-

${ }^{65}$ Libellus de arte dictandi rhetorice is edited in Camargo, Medieval Rhetorics, pp. 37-87; henceforth references are cited by line numbers from this edition. For date and attribution, see Worstbrock, Klaes, and Lütten, Repertorium, pp. 90-92. The sole surviving copy, in Cambridge University Library, MS Dd. 9. 38, was written in England during the third quarter of the fourteenth century and once belonged to the Benedictine abbey at Reading. A second copy, now lost, is recorded in a book list for Dover Priory, also Benedictine.

${ }^{66}$ The text is printed in Janson, Prose Rhythm, pp. 118-19. For discussion and extensive bibliography, see Worstbrock, Klaes, and Lütten, Repertorium, pp. 134-35.

${ }^{67}$ W itt, 'On Bene of Florence', pp. 94-95. Tore Janson had supported Bene da Firenze's account and argued that dictatores in the schools of Orléans and Meung had repackaged the local style of cursus as the cursus romane curie: Janson, Prose Rhythm, pp. 96-97. 
lized a perennial problem of rhetorical techné. The passage also makes a more narrowly historical intervention. Peter's Libellus is, together with the instructions attributed to Albert de Morra, one of the earliest surviving accounts of cursus. By advertising cursus as a trade secret useful to an aspiring chancery clerk, Peter emphasizes the element that distinguishes his teaching from that currently available from other sources - sources named in the treatise's Prologue (1l.3-12). Moreover, the specific location of the cursus instruction ensures that it will not be overlooked: it is preceded only by the Prologue and an account of the three distinctiones.

Given that instruction in prose rhythm was not a routine component of artes dictandi when Peter of Blois wrote, he perhaps felt free to place instructions on this subject where he wished. Yet, in the centuries that followed, cursus tended to remain, in James Murphy's phrase, an 'undigested whole' within the architecture of the artes dictandi. ${ }^{68}$ Dictatores occasionally treated cursus near the beginning of their treatises, as Peter of Blois did; more often, they relegated cursus to an appendix. ${ }^{69}$ Murphy speculated that teachers ' $\mathrm{d}[\mathrm{id}]$ not know what use to recommend for an imported system that [was] already well developed'. $7^{70}$ While Peter's Libellus betrays no doubts about the proper use of cursus, the use that it recommends is peculiar. Within the system of classical rhetoric, rhythm should be comprehended as a device of ornamentation and its use guided by the fundamental structuring opposition between virtutes and vitia. ${ }^{71}$ Many artes dictandi approximated this classical system: the cursus might be described as adding ornamentation, elegance, and balance. ${ }^{72}$ However, Peter's Libellus does not

${ }^{68}$ Murphy, Rhetoric in the Middle Ages', p. 253.

${ }^{69}$ An example of cursus treated at the end of a manual is Thomas Sampson's Modus dictandi, edited in Camargo, Medieval Rhetorics, pp. 148-68. The semi-independence of cursus instructions from ars dictaminis is also demonstrated by the independent circulation of instructions in cursus; sometimes two or more sets of instructions are copied one after another. For examples, see Camargo, Medieval Rhetorics, pp. 31 n. 110, 102-03, and 149 n. 5.

${ }^{70}$ Murphy, Rhetoric in the Middle Ages, p. 253.

${ }^{71}$ On prose rhythm in classical rhetorical theory, see Heinrich Lausberg, Handbook of Literary Rhetoric: A Foundation for Literary Study, ed. by David E. Orton and R. Dean Anderson, trans. by Matthew T. Bliss, Annemiek Jansen, and David E. Orton (Leiden: Brill, 1998), \$\$ 977-1054. For the structuring opposition between virtutes and vitia, see $\$ \$ 8$ and 458 .

${ }^{72}$ For example, the thirteenth-century French teacher Pontius of Provence writes, 'Cursus est matrimonium spondeorum cum dactilis prolatione lepida celebratum. Ad hoc enim cursus inventus est, ut per eum vocalium et cuiusque vocis asperitas evitetur; et hoc secundum antiquos. Secundum vero modernos cursus inventus est, ut per eum competentius et magis ornate clausula 
recommend the cursus in these terms: rather than taking its place as one compositional precept among others, cursus has acquired the status of a unique and authorizing badge. It has become dislocated from the system of classical rhetoric and now exercises the function of a surplus value. ${ }^{73}$ Moreover, this dislocation with respect to classical rhetorical theory is not limited to the manuals that make explicit supplementary claims for the value of prose rhythm. From the perspective of classical rhetoric, the standard mode of presentation of cursus might itself appear to be flawed: artes dictandi typically present the doctrine of cursus in a categorical mode, framed as rules to be followed rather than as resources to be employed at the writer's discretion. Voicing the position of classical rhetorical theory, Boncompagno mocked other teachers of ars dictaminis as magistri dactylii and denounced their way of isolating and legislating rules for this particular aspect of discourse:

To issue a single set of definite and binding rules involving dactyls and spondees for the beginnings and ends of prose clauses would not, therefore, be a sensible doctrine, but instead the utter confusion of the dictatores. ${ }^{74}$

From Boncompagno's perspective, the dictatores appear to have a partial - that is, incomplete and unbalanced - understanding of prose rhythm. What I hope to show here is that partial forms of attention to cursus can be read as indexes of the forces that acted upon teaching and learning of ars dictaminis. The categorical mode of instruction in cursus could perhaps be compared to the codification of

et tota epistola proferatur' (Cursus is the marriage of spondees with dactyls, commemorated with an elegant delivery. Indeed, cursus was developed in order to avoid the rough collision of vowels and of any other sound. This is what the ancients say. According to recent writers, cursus was developed so that the clause and letter as a whole might be delivered with better agreement and more ornamentation): printed in Charles Thurot, Notices et extraits de divers manuscrits Latins pour servir à l'histoire de doctrines grammaticales au moyen-âge (Paris: Imprimerie impériale, 1868), p. 481. Drawing from Bene da Firenze's Candelabrum, Martin Camargo shows how instructions on compositio, including cursus, would have contributed to the clarity of oral delivery: Camargo, 'Special Delivery: Were Medieval Letter Writers Trained in Performance?', in Rhetoric Beyond Words: Delight and Persuasion in the Arts of the Middle Ages, ed. by Mary Carruthers (Cambridge: Cambridge University Press, 2009), pp. 173-89 (p. 179).

${ }^{73}$ I have in mind Jacques Lacan's re-derivation of Marx's concept: see Lacan, The Other Side of Psychoanalysis, trans. by Russell Grigg, Seminar of Jacques Lacan, 17 (New York: Norton, 2007). See also Dylan Evans, An Introductory Dictionary of Lacanian Psychoanalysis (London: Routledge, 1996), s.v. 'part-object (objet partiel)' and 'objet (petit) $a$ '.

${ }^{74}$ Quoted in Valois, 'Étude sur le rythme des bulles pontificales', p. 196. For Latin text, see n. 98 , below. 
salutations, inasmuch as both developments tended to reduce the scope of individual judgement. However, the forms of attention to and investment in cursus I examine in the remainder of this essay do not, I think, lend themselves to a purely functionalist explanation. The Libellus de arte dictandi rhetorice shows how cursus could acquire the function of a surplus value. In the fourteenth and fifteenth centuries, manuals continued to describe their teaching as the cursus romane curie, although without thematizing the papal connection as Peter of Blois had. The fourteenth- and fifteenth-century manuals that take the most pronounced interest in cursus do not show textual dependence on the Libellus and cannot be said to share a common understanding of the meaning or value of the cursus. Instead, what they share, yet realize differently in each case, is simply their partiality towards this feature of ars dictaminis.

The first of the three treatises that I wish to examine is an anonymous compilation probably dating from the late fourteenth century, though incorporating materials considerably older. I will call the treatise Cum inter iocunda, from its incipit. Components occur in at least eleven manuscripts; in its fullest copies, it consists of the following major parts: ${ }^{75}$

(1) A prologue, followed by instructions in cursus. The treatment of cursus agrees very closely in organization, wording, and examples with the slightly briefer instructions in Thomas Merke's Formula moderni et usitati dictaminis (11. 514-54). All examples except for the last two (printed in the text below) also appear in Merke's treatise.

(2) A second set of instructions in cursus, recommending the same rhythmical patterns, but adding an alternative word division for cursustardus and employing a more complicated metrical terminology. Related treatments of cursus are printed in Camargo, Medieval Rhetorics, p. 97, 11. 151-56, and pp. 102-03.

${ }^{75}$ The following outline and conspectus of manuscripts uses materials that Martin Camargo has generously shared with me, part of his work in progress on treatments of figures in the late twelfth and early thirteenth centuries. The two fullest copies of Cum inter iocunda are London, British Library, MS Harley 3224, fols $54^{\mathrm{r}}-66^{\mathrm{v}}$, and Oxford, Balliol College, MS 263, fols $1^{\mathrm{ra}}-4^{\mathrm{va}}$. Three other copies present some portion of Parts I-III followed by some portion of Parts IV and V: London, British Library, MS Cotton Cleopatra B.6, fols $234^{\mathrm{r}}-237^{\mathrm{v}}$; London, British Library, MS Cotton Nero A. 4, fols 155 $-157^{\mathrm{v}}$; and London, British Library, MS Harley 3300, fols $177^{\mathrm{v}}-179^{\mathrm{r}}$. Components occur in six additional manuscripts: Cambridge, Corpus Christi College, MS 358; Cambridge, Trinity College, MS R.14.40; Douai, Bibliothèque municipale, MS 764; Oxford, Bodleian Library, MS Bodley 310; Oxford, Bodleian Library, MS Bodley 832; Oxford, Magdalen College, MS lat. 6. 
(3) Treatment of the division of sentences, or three distinctiones: coma, colon, and periodus.

(4) Definition and exemplification of rhetorical colors and ornamentation, drawing on Book IV of the Rhetorica ad Herennium.

(5) A laudatory dedication, followed by model compositions.

Martin Camargo is preparing an edition of Parts IV and V, which occur separately in Trinity College, MS R.14.40, pp. 356a-362a, a manuscript of the early thirteenth century. All other manuscripts date from the fourteenth or fifteenth centuries. Two manuscripts provide titles in the incipit or explicit: 'Forma dictandi' (Harley 3224, fol. 66 ) and 'Ars dictandi' (Bodley 310, fol. $148^{\text {rb }}$ ). In a third copy, Part II has its own title, 'Forma dictandi secundum stilum Curie Romane' (Harley 3300, fol. 178). However, as shown in the above outline of contents, the instructions in cursus are the only materials belonging specifically to the tradition of ars dictaminis. There is no instruction on the correct forms of salutation, nor indeed any enumeration of the letter's standard parts. Despite scribal titles, Cum inter iocunda is not an ars dictandi. Yet letter-writing still serves as the treatise's point of departure, in a prefatory gesture towards a recent conversation de epistolaris natura dictaminis: ${ }^{76}$

Cum inter iocunda familiarit< $<$ atis colloquia $>{ }^{77}$ de epistolaris natúra dictáminis/ nuper mi dillectissime $\mathrm{e}^{78}$ si recolitis aliquantulum adínuicem tractarémus/ et nec loci nec temporis tunc permísit congrúitas/ materiam illam verbotenus vt décuit explicári/ disposuit vestra discrécio circumspécta ${ }^{79}$ vt quod pro tunc lingua retéxere ${ }^{80}$ non valébat/ suppleret cálamus per scriptúram. SCupiens ${ }^{81}$ igitur prout teneor ${ }^{\overline{82}}$ iuxta mee possibilitatis modulum

${ }^{76}$ I print the text of MS Balliol 263, fol. $1^{\text {ra }}(\mathrm{B})$, and record substantive variants from the four other copies of Part I: MSS Harley 3224, fol. $54^{\mathrm{r}}(\mathrm{H})$, Harley 3300, fol. $177^{\mathrm{V}}(\mathrm{A})$, Cotton Cleopatra B.6, fol. $234^{\mathrm{r}}(\mathrm{L})$, and Bodley 310 , fol. $148^{\mathrm{rb}}(\mathrm{O})$. One correction to B is enclosed in pointed brackets. When no sigla follow the lemma, the printed reading is the reading of $\mathrm{B}$ and any other manuscripts whose reading is not recorded as variant. I silently expand abbreviations and add accent marks and underlining to draw attention to cursus; BHL and (less regularly) O mark distinctiones with punctus or punctus elevati, represented here by virgules. Punctuation is not absolutely consistent among these manuscripts; I place a virgule whenever one of the copies BHL punctuates.

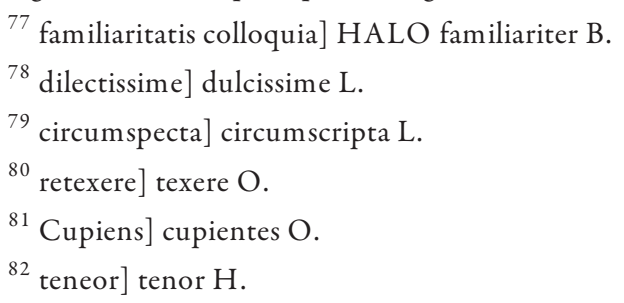


satisfácere votis véstris/ quedam puerilia que primo aspectu epistolaris concernunt ápicis venustátem videlicet de mensura diccionum ${ }^{83}$ epistole clausulas terminancium duxi preséntibus inserénda.

(Recently, during a pleasant and friendly conversation, we were (if you recall, my very dear friend) making a little joint enquiry in to the nature of epistolary composition; because proprieties of time and place did not then allow the matter to be explained in detail as it deserved to be, your provident judgement arranged for a pen to supply in writing what the tongue did not then manage to relate. Therefore, desiring to satisfy your wishes (accordingly as I am bound to do, but in proportion with my limited capacity), I considered it appropriate to include, in this present text, some trivialities which, in first impressions, pertain to the elegance of epistolary writing: specifically, the measure of the words that conclude a letter's clauses.)

Jean Leclercq reminds us of the close affinity between letters and dedicatory prologues (both are discourses shaped by address) and draws our attention to expressions of friendly devotion in letters. ${ }^{84}$ Both points are relevant to this treatise, where expressions of friendship, established in the Prologue, extend into the subsequent teaching. For example, as illustration of the cursus planus, the treatise provides the following: "Vtinam ille cui cordis mei potestas in omnibus est concessa suis me litteris recreáre curáret' (Oh, I wish that he to whom I surrendered my heart's dominion in all things would have bothered to revive me with his letters). ${ }^{85}$ The author summarizes his teaching with two sentences (omitted from Merke's account) illustrating the three cadences - planus, tardus, and velox - in their appropriate positions: ${ }^{86}$

SEt om nes istos tres modos in tribus distinccionibus clausule subsequentis liquido poteris intueri: 'Non semel sed sepius in ménte reuóluo (prima) quam felicem quamque iocundam

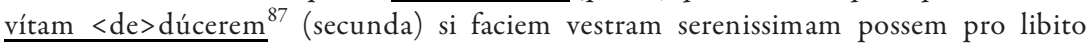
respicere reuelatam'. Vel sic: 'Melius in vita vel iocundius nichil michi fortuna pósset donáre / quam vt colloquiis vestris dulcissimis me frequencius úti permítteret (secunda) et in libris mella stillantibus scríbere cum libéret (tertia)'.

(And you will be able to observe all three of these modes clearly in the following sentence's three distinctions: 'Not one time only, but very often, my thoughts turn to what a happy

${ }^{83}$ videlicet ... diccionum] de mensura diccionum videlicet $H$.

${ }^{84}$ Jean Leclercq, 'Le Genre epistolaire au moyen âge', Revue du moyen âge latin, 2 (1946), 63-70 (p. 64). For expressions of friendship, see Leclercq, 'L'Amité', pp. 400-10.

${ }^{85}$ MS Harley 3224 , fol. $54^{\mathrm{v}}$. MS Balliol 263 is damaged at this point.

${ }^{86}$ MS Balliol 263, fol. $1^{\text {rb }}$. I record readings from other manuscripts only to correct B. Virgule and parentheses represent punctuation in $\mathrm{B}$.

${ }^{87}$ deducerem] ALO ducerem BH. 
and pleasant life I might have led, had I been able to look directly upon your most peaceful face whenever I wished.' Or like this: 'Fortune could have given me nothing in this life either better or more pleasing than the following: that I be permitted to enjoy your delicious conversation very often and to w rite whenever I wished in honey-glazed books.')

All told, nine of the model sentences can be said to extend the affectionate protestations of the Prologue. Thematic continuity between the Prologue and the following instructions in cursus suggests that Merke borrowed from Cum inter iocunda rather than vice versa. Indeed, it is possible that Part I was composed independently of Parts II-V and had prior independent circulation: it occurs alone once, in MS Bodley 310, where it is the only rhetorical item in the manuscript. ${ }^{88}$ By contrast, the other four copies of Part I occur with rhetorical or dictaminal materials. MS Harley 3300 is a register of the episcopal chancery at Exeter, written in several fifteenth-century hands. ${ }^{89}$ The remaining three manuscripts - Harley 3224, Cotton Cleopatra B.6, and Balliol 263 - are all Oxford Readers dating from the late fourteenth or first half of the fifteenth centuries. ${ }^{90}$

${ }^{88}$ MS Bodley 310 is a composite volume, consisting of two separate books probably bound together late. The second part (fols 146-300), written uniformly in an anglicana script dated to the late fourteenth century, was initially constructed for a single item, here provided with the scribal title 'liber memorialis milicie'. A reduced preliminary quire (fols 146-50) contains Cum inter iocunda (Part I only), together with two Latin poems on conduct and an index to the 'Liber memorialis milicie'. See Falconer Madan and H. H. E. Craster, A Summary Catalogue of Western Manuscripts in the Bodleian Library at Oxford, 7 vols in 8 (Oxford: Clarendon Press, 1895-1953), II (1922), pt I, no. 2121 (pp. 219-20); and Adolar Zumkeller, Manuskripte von Werken der Autoren des Augustiner-Eremitenordens in mitteleuropäischen Bibliotheken (W ürzburg: Augustinus, 1966), nos 166, 174.

${ }^{89}$ Martin Camargo, 'Two Middle English Carols from an Exeter Manuscript', Medium Evum, 67 (1998), 104-11.

${ }^{90}$ MS Harley 3224 is written on parchment in a clear, minimally abbreviated anglicana formata with some influence of secretary. Other contents are Alain de Lille, De planctu nature; Richard de Bury, Philobiblon; and Jean de Limoges, Morale somnium Pharaonis. An ownership note on folio 1 shows that the book belonged to William Weld, Benedictine, doctor of canon law, and Abbot of St Augustine's Abbey, Canterbury, from 1387 until his death in 1405. See A. B. Emden, $A$ Biographical Register of the University of Oxford to A.D. 1500 (Oxford: Clarendon Press, 1957), p. 2007. Cotton Cleopatra B.6 is described in Margaret T. Gibson, Danuta R. Shanzer and Nigel F. Palmer, 'Manuscripts of Alan of Lille, 'Anticlaudianus' in the British Isles', Studi Medievali, 28 (1987), 905-1001 (pp. 965-67). Balliol 263 is described, most recently, in Camargo, Medieval Rhetorics, p. 109, with further references. Additionally, Part I probably also occurred in another Oxford Reader, Douai, Bibliothèque municipale, MS 764. This codex now begins imperfectly, with a leaf containing the end of Cum inter iocunda, Part V; remaining contents correspond closely to those of MS Balliol 263. 
Repeat occurrences in Oxford Readers, Thomas Merke's access to cursus instructions, and the compiler's access to rare twelfth-century rhetorica all suggest that Cum inter iocunda was a product of the late fourteenth-century Oxford revival in literary grammar and rhetoric. This field placement has implications for the treatise's presentation of cursus. As one would expect, the author of Cum inter iocunda observes cursus in his prologue, including a striking sequence of two cursus veloces at the end of the first period. He praises cursus for contributing to a letter's elegance; yet, simultaneously, he wraps his teaching in qualification and condescension. He projects desire for instruction onto his addressee and hastens to meet that desire, but he also maintains a distance from the content of his teaching. The point is not that the author was not serious about cursus, but instead that, in the context of advanced instruction in literary style, cursus might justifiably appear to be child's play - puerilia, as our author says. His delicate balance of participation in and distantiation from cursus would be appropriate to the literary-rhetorical school of dictamen, where cursus could be subordinated within comprehensive rhetorical instruction. More generally, the opposing tendencies of participation and distantiation recall monastic attitudes towards classical and literary studies, as described by Jean Leclercq. ${ }^{91}$ Benedictine authorship is possible: MS Harley 3224 has a Benedictine provenance and Benedictines played key roles in the revival of literary rhetoric in later fourteenth-century Oxford. The author's delicately modulated condescension to the content of his teaching contrasts sharply with the next two manuals.

While composed after Cum inter iocunda, Simon O.'s Summa dictaminis embodies the fixation on cursus from which the author of Cum inter iocunda distances and distinguishes himself. The Summa dictandi of Simon O. and a closely related anonymous textbook with the incipit Regina sedens rhetorica both date from the first quarter of the fifteenth century. ${ }^{92}$ Stylistic, verbal, and doctrinal correspondences between the two treatises raise the possibility of common authorship. ${ }^{33}$ Both recommend exceptionally long and various patterns of cursus,

${ }^{91}$ Jean Leclercq, The Love of Learning and the Desire for God: A Study of Monastic Culture, trans. by Catharine Misrahi (New York: Fordham University Press, 1982), pp. 112-50.

92 The Summa dictandi of Simon O. is edited in part in Pantin, 'A Medieval Treatise on Letter-Writing; hereafter references to the Summa dictandi are cited by page number from this edition. For discussion, see also Richardson, 'An Oxford Teacher'. Regina sedens rhetorica is edited in Camargo, Medieval Rhetorics, pp. 169-219 (see n. 5, above); hereafter references to this work are cited by line numbers from this edition.

${ }^{93}$ On the relationship between the two treatises, see Richardson, 'An Oxford Teacher', pp. 437-38, and Camargo, Medieval Rhetorics, pp. 171-72. For Simon's name - the initial O. is 
employing a metrical terminology in which cadences are described as combinations of dactyls and spondees. Both make cursus their first item of instruction. Regina sedens rhetorica employs a remarkable allegorical frame that I will examine at the end of this essay. Simon O. introduces cursus as follows: he asserts that ignorance is the evil step-mother of disciplinary practice and that ignorance of cursus is a chief reason why writing in his day falls short of its capacity to inspire pleasure in young minds. In order to correct this ignorance, he begins at the end, that is, with clause endings (pp. 333-34). He deduces the importance of clause endings from a standard definition of dictamen: ${ }^{94}$

Dictamen est litteralis edicio venustate sermonum et egregia sentencia coloribus ornata, per quam quidem diffinicionem, que et qualis sit cadencia, attente scire poterit perspicuus indagator, cuius venustatis ardentia ${ }^{95}$ extat, quia cadencia nichil aliud esse poterit nisi distinccionis vel scissure et precipue diccionum finalis clausura. (p. 334)

(Dictamen is a written utterance decorated in elegant words and a striking statement decorated with rhetorical colours. From this definition a sharp investigator who has a passion for elegance may, with care, learn what sort of thing cadencia is. For cadencia could not be anything other than the final closure of clauses or phrases, and especially of words.)

Passion (ardencia) for elegance will point the way to knowledge of cursus (cadencia). The scribe had trouble distinguishing the one from the other, miswriting ardentia for cadentia several times in the subsequent text. At the conclusion of the account of cursus, Simon acknowledges that some of his recommendations are unconventional, but insults those who object and says that the extended range of cadences was developed by philosophi:

Quidam ignari forsitan temere prorumpent, quod huiusmodi term inciones non continentur sub serie cadenciarum: qui stolide delirant, quod inquiunt ignorantes. Nam huiusmodi terminaciones philosophi invenerunt, qui veritatem sunt prosecuti, pro sentenciis observandis, $\mathrm{qu}<\mathrm{ia}>$ deficile esset eis et sermonistis ac collacionum compositoribus sub una

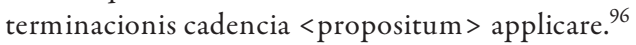

expanded to 'Oxenford' in one manuscript - see Camargo, Medieval Rhetorics, p. 172 n. 7 , with references.

${ }^{94}$ The definition is traceable ultimately to Bernard of Meung: see Murphy, Rhetoric in the Middle Ages, p. 227 n. 66; and Worstbrock, 'Ars dictandi in Frankreich', p. 139.

95 Pantin emended to '<ca>dencia'. The scribe has miswritten 'cadencia' as 'ardencia' on several other occasions before and after this passage, but this instance is probably correct.

${ }^{96}$ Summa dictandi, p. 336. The manuscript reading, which Pantin retained but marked as corrupt, is 'quas deficile [...] sub una propositum terminacionis cadencia applicare'. 
(Certain idiots may boldly blurt out that terminations of this sort are not included in the set of cadences. These people ignorantly rave, for they speak without understanding. Indeed, philosophers who seek out the truth devised terminations of this sort in order to preserve their meanings: for it would be difficult for them and for preachers and composers of homilies to attach their intention to a single termination's cadence.)

The significance of Simon's reference to philosophi - 'philosophers', or perhaps more simply, 'learned men' - can be elucidated by comparison with Italian dictatores. In his Candelabrum, Bene da Firenze reminded students that the precepts of compositio - in which he includes cursus - are 'honoured by famous authors and philosophers, nor is any letter sent from the Roman See without such ornament'. ${ }^{97}$ Boncompagno da Signa, Bene's contemporary and rival, invoked the authority of ancient philosophi to support a far more sceptical assessment of cursus, part of which I have already quoted:

Ancient philosophers retained ordinary word-order because they were interested in the concrete signification and force of statements, rather than in verbal ornament. For this reason, they set down individual words in just the way the words occurred to them. To issue a single set of definite and binding rules involving dactyls and spondees for the beginnings and ends of prose clauses would not, therefore, be a sensible doctrine, but instead the utter confusion of the dictatores. ${ }^{98}$

Boncompagno is exaggerating. He employs cursus in this passage and does not mean to recommend that it be abandoned. Instead, his point is that rules are the wrong modality in which to treat something like style, which ought to be adjustable to the speech act's total character and aims. In this respect, as in others, Boncompagno was defending the position of classical rhetoric, as Ronald Witt has shown. ${ }^{99}$ Moreover, what Boncompagno says about philosophy's stylistic preferences has some merit as a description of thirteenth-century philosophical prose, in which scholars strove to render the complex meanings of the ancient authors

97 '[C]ompositionis artificium [...] est apud nobiles autores et philosophos in honore, nec a sede Romana sine tali decore aliqua epistola destinatur': Candelabrum, I. 8. 8. Quotation and translation from Camargo, 'Special Delivery', pp. 179 and 187 n. 22.

98 'Comunem dicionum ordinationem antiqui phy<lo $>$ sophi observabant quia de intellectu materiali et pondere scentenciarum curabant, amplius quam de ornatu verborum; quare ordinabant singulas dictiones, prout eis casualiter occurrebant. Dare igitur sub una forma certas et necessarias regulas in prosa de datilis et spondeis, principiis et finibus clausularum, nec esset doctrina salutifera, sed perpetua confusio dictatorum': qtd. in Valois, 'Étude sur le rythme des bulles pontificales', p. 196.

${ }^{99}$ Witt, 'Boncompagno', pp. 16 and 23-24. 
in 'clear, simple, and unadorned language'. ${ }^{100}$ In both respects, the contrast with Simon O.'s comments on cursus and philosophi could not be greater. Where Boncompagno recommends moderating the regularity of the stylistic rule, Simon doubles down. If the rules of correct style are felt to impede communication, then, according to Simon's ardent reasoning, the set of rules should be expanded.

Can Simon's claims for cursus be elucidated by locating him within the field of education? Formularies attached to both Simon's treatise and Regina sedens rethorica show Oxford connections. Besides the Summa dictandi, the only work definitely attributable to Simon O. is a treatise on conveyancing, which contains frequent references to Oxford. ${ }^{101}$ Since conveyancing was a standard subject in the business course, this manual has been taken as evidence that Simon was a business teacher. The identification is probably correct, but immediately requires qualification. The conveyancing manual, Simon's ars dictandi, and Regina sedens rhetorica all share a Latin style that is more ornate than the Latin artes dictandi of the business course, while also more obscure and laboured than the literary-rhetorical artes dictandi. ${ }^{102}$ If language and style distinguish Simon and the Regina-author from the business teachers, one of the letters that accompanies Simon's ars dictandi develops this stylistic point of distinction as its theme. ${ }^{103}$ The letter writer, who styles himself a follower of Queen Rhetoric, attempts to persuade a friend (apparently involved in business administration) to return to his rightful queen and first nurse. The letter elaborately praises Queen Rhetoric, especially for the rich rewards that she bestows on her faithful, studious, and virtuous followers. Rhetoric herself tearfully laments that one of the children whom she nourished with her own milk and raised in her own crib has now entered into an unholy union with the Queen of the Exchequer ('sed nephande scaccarum regine se

${ }^{100}$ Charles F. Briggs, 'Translation as Pedagogy: Academic Discourse and Changing Attitudes Toward Latin in the Thirteenth and Fourteenth Centuries', in Frontiers: Proceedings of the Third European Congress of Medieval Studies (Jyväskylä, 10-14 June 2003), ed. by Outi Merisalo, Textes et études du moyen âge, 35 (Louvain-la-Neuve: Fédération internationale des Instituts d'études médiévales, 2006), pp. 495-505 (p. 502).

${ }^{101}$ Richardson, 'An Oxford Teacher', pp. 438-44.

${ }^{102}$ See comments on style in Pantin, 'A Medieval Treatise on Letter-Writing', p. 330; Richardson, 'An Oxford Teacher', pp. 438-40; and Camargo, Medieval Rhetorics, p. 171. More generally, on pre-humanist Latin eloquence in fifteenth-century England, see E. F. Jacob, 'Florida Verborum Venustas: Some Early Examples of Euphuism in England', Bulletin of the John Rylands University Library of Manchester, 17 (1933), 264-90.

103 The letter is calendared in Pantin, 'A Medieval Treatise on Letter-Writing', p. 371, and printed in Camargo, Medieval Rhetorics, pp. 220-21. 
copulauit nequissime maritandum'). The writer promises his friend that, if he detaches himself from the hairy, wrinkled, and filthy (fedosa) Queen of the Exchequer, the road back to the court of Rhetoric will be neither hard nor rocky for him, since Peticio, Annominacio, Conuersio, and Gradacio will serve as his escorts. This allegorical letter is followed in Simon's formulary by another ornate composition in which advice to a friend at court occasions a display of rhetorical figures.

Together, the two letters provide a suitably rhetorical reply to the letters of Thomas Sampson, in which a father writes to a son and counsels him to transfer from the arts course to Sampson's school, in preparation for a promised appointment at court. Indeed, Simon's allegorical letter might, as a whole, be considered to illustrate the figure ironia: as the author of a treatise on conveyancing, Simon could, as Martin Camargo remarks, be 'charged with aiding and abetting the very apostasy that this letter pretended to combat'. ${ }^{104}$ The contradiction expressed in Simon's teaching materials perhaps corresponds to a fairly narrow historical moment. In 1432, about fifteen years after Simon's activity, Oxford university asserted its right to license, supervise, and collect fees from the town's business teachers, who had previously operated independently. ${ }^{105}$ This 1432 statute seems to have provoked a reorganization of field, such that, by mid-century, David Pencaer could teach and adapt materials from both branches of ars dictaminis. Evidently, during the first quarter of the century, the disciplinary division between the two branches of ars dictaminis was still sufficiently in force to leave its mark on the work of Simon and the Regina-author. In terms of language, style, and theme, Simon's teaching was divided against itself in an effort to distinguish itself. His model letter on Queen Rhetoric and his defensive reference to philosophi can perhaps be understood as efforts to align his teaching with traditions of literate pedagogy more prestigious and autonomous than that of business training. It is possible that dictamen's position and functions within the educational field may have predisposed the discipline's teachers towards efforts at exceptionality.

I have attempted to show the extent to which Simon O.'s manual expresses and responds to its position in a field. My final specimen shares many of the characteristics of Simon's manual, but, at the level of theme, is oriented much

${ }^{104}$ Camargo, 'If You Can't Join Them, Beat Them', p. 75.

105 The statute is printed in Statuta antiqua universitatis oxoniensis, ed. by Gibson, pp. 240-41. For discussion, see Camargo, 'If You Can't Join Them, Beat Them', pp. 67-87, especially his account of Pencaer, pp. 76-77. 
more explicitly towards the careers for which it prepared its students. Regina sedens rhetorica uniquely sets dictaminal teaching within a personification allegory, beginning with an exchange in which Queen Rhetoric establishes the personified metrical constituents of cursus as members of her household retinue. This opening is worth quoting at some length:

Regina sedens Rethorica in suo solio maiestatis, Philomenam sui thalami secretariam ad se dulciter conuocauit, eidem inquiens in hec verba: 'D ulcissima, tue prudencie dinoscitur minime collatere quod tot et tantos meo hospicio possideo sectatores, qui in sui famulatus ac gradus genere cissuris aureis et fimbriis bissinis debeant inuestiri, qui eciam, propter colorum caristiam, indui non possunt absque consilio saniori.

'Ideo precor te, venustatis prouide mellicam Philomenam, quatinus mei hospicii pro huius negocii vestigio captatis discrecioribus, vt mee fame preconium vndique obseruetur, huiusmodi tunicas et colores disponere satagas. Necnon pro huius festi laudiflua solem pnitate tales pro continuo capelle nostre ministerio preordines cantores, dulci cum organo, quorum modulamina, sue dulciflue armonie prestrictu, ascultancium auriculas spiritali pabulo intonisent. Quos tuo tenore dulcifluo preuies sertarie concordancie vestigio, vt precentor in ordine cum tuis vassallis Dactulo et Spondeo sagaciter obseruando, quos in suis officiis ab aliis discernere oporteat, ne forsan quidam dissoni in toni concordancia deficiant et prolatu.

'Quomodo quidem Dactulum cognoscere valeat? Induens breui tunica et succincta, videlicet quam libet diccionem penultimam habentem correptam, vt "dominus", "angelus", "spiritus", vocabulo dactulum appelamus. Ymmo secundus vasallus, videlicet Spondeus, suam similiter cognoscitur per vesturam. Nam quocum que loco perrexerit togam induitur prolixam; scilicet quelibet diccio habens penultimam longam, vt "caligo", "amator", "suppremus" et omne dissillabum seu bissillabum, vt "missa", "dicta”, "caput", "dolet" et huiusmodi spondeus vocabitur. Et hii duo vasalli officia preordinant tam celebriter edicenda, sine quibus ad huius conuiuii epulas seu seraturas nullus poterit inuitari. ${ }^{106}$

'Et dulcis Philomena, iam cum tempus arripuit, presentis festi, tenore cum mellico, officium preconisa.'

'Mea domina singularissima, primi toni cantus incipiam in spondeo quatuor sillabarum cum dactulo precedente.'

'Dulcissima Philomena, organisa tunc.'

'Nostri festi salutiferum reputo officium laudibus Deum extollere gloriosum.'

'Philomena, iste cantus est dulcissimus.'

(Queen Rhetoric, seated on her royal throne, has sweetly summoned Philomela, secretary of her chamber, into her presence and now addresses these words to her: 'Sweetest, we

${ }^{106}$ Compare ll. 422-24 and similar language near the end of Simon's Summa dictandi: 'quibus [sc. litteris ornate contextis] et normulis precedentibus aperiet seraturas oculti archani nostri, sine quibus ad huiusmodi convivii epulas non vocetur' (p. 340). 
know it has not escaped your wise notice that I retain a great many followers here in my household, followers who ought to be outfitted for their type of service and rank and clothed with golden garments (cissuris) ${ }^{107}$ and satin fringes. Yet a dearth of colours (colorum) prevents them from being outfitted, at least not without sharper counsel.

'Therefore I ask you, Philomela, who are enhanced with prudent elegance, to take charge of distributing coloured tunics of this sort to the choicest and most distinguished of my household's retainers as the emblem for this undertaking, so that the proclamation of my fame will be recognized everywhere. Also, on account of the festival's congratulatory solem nity, you should appoint singers to serve continuously in a sweet arrangement at our chapel. Their singing, having the concision of a mellifluous harmony, will serenade the ears of listeners with spiritual nourishment. As lead singer, you will go in advance of the others with your mellifluous theme, the emblem of interlaced consonance. You will be attended by your servants Dactyl and Spondee in an arrangement requiring intelligent oversight. It is important to distinguish the offices of Dactyl and Spondee from those of the others, so as to prevent the dissonant ones from mangling the tune's consonance and delivery.

'Indeed, how is one to identify Dactyl? He wears a short and cropped garment. So, any word having a short penultimate syllable, such as "dominus", "angelus", "spiritus", we call by the name "dactyl". And indeed, the second servant - Spondee — is similarly identified by his clothing, for wherever he travels, he wears a long robe. So, any word having a long penultimate syllable, such as "caligo", "amator", "suppremus" and all disyllabic or two-syllable words, such as "missa", "dicta", "caput", "dolet" and others of this sort are called "spondees". And these two servants perform offices that ought to be proclaimed widely, for without them no one could be invited to this closed-door banquet and feast.

'And sweet Philomela, since time has now slipped aw ay, proclaim the present celebration's office with a honeyed accent.'

'My one-and-only mistress, I shall begin singing the first tune with a spondee of four syllables preceded by a dactyl' [This is cursus velox].

'Then perform it, sweetest Philomela.'

'I believe that our celebration's wholesome office elevates glorious God with praise (extóllere gloriósum)’.

'Philomela, that song is very sweet'.)

In this allegory, the standard metrical terminology of cursus is given a sartorial twist: the dactyl will be clothed in a short and cropped garment ('breui tunica et succincta'), while the spondee wears a long robe ('togam [...] prolixam'). Thus attired, rhythmical clausulae will convene 'epulas seu seraturas', a private dinner at the court of Rhetoric. There is a note of ostentatious exclusivity here, not

107 The word will later be used for a segment of a sentence: see 1l. 142, 164-69. 
unlike the description of cursus as a papal trade secret in the Libellus de arte dictandi rhetorice. But before these messengers can issue their invitations and spread their Queen's fame abroad, their proper sequences must be established: this is Philomela's task at the end of the passage above. She recites six arrangements of dactyl and spondee before exhaustion sets in ('Iam [...] suis lacescita modulaminibus'; 1. 63), at which point she calls upon a series of kindred helpers - a thrush, wren, rooster, and hoopoe - to complete the task. Next, Coma, Colon, and Periodon are summoned into the Queen's presence. They are identified, respectively, as her chancellor (cancellarius), treasurer (thesaurius), and almoner (aumonarius) (11.107-10). The three receive their assignments from the Queen and take up their proper positions. Coma then advises the Queen that she should designate a host or steward to oversee her royal hall: 'aularium, hostiarium seu senescallum vos disponere iam oportet' (11. 172-73). This office is to be filled by one Dictamen, apparently unknown to Coma, who asks, 'Dictamen quid est?' (1. 175). Coma's question has the form of Donatus' grammatical catechism, but the Queen has been playing the leading role in this dialogue; she responds with the conventional definition that we have already seen in Simon O.'s Summa dictaminis. Commentary on this definition of dictamen leads into discussion of colores and then into a long illustration of methods for varying and empurpling prose - methods enthusiastically practised in the treatise's opening paragraphs and in the letters that follow. The manual ends with a brief identification of the letter's parts (11. 433-67). Illustration is kept to a minimum in this section: readers seeking more detail, including appropriate formulas for the salutation, are referred to the subsequent collection of letters (1. 440; cf. 11. 463-567).

Thus, the treatise embeds its teaching in a personification allegory and parliament of birds. Whatever reservations one may have about the author's style, his allegorical fiction corresponds in some respects to Douglas Kelly's description of the medieval rhetorical 'masterpiece', a literary fiction exemplifying the teaching contained in textbooks of rhetoric. ${ }^{108}$ This rhetorical fiction would repay more detailed attention; the assimilation of cursus to music is particularly striking, both in the opening provisions for a chorus and again in the bird-song that delivers instruction in cursus. Here I will draw out and comment on only one of the fiction's motifs: its mapping of dictaminal teaching onto a household staff. The dactyl and spondee, as elements of cursus, are appointed as the Queen's chantry

${ }^{108}$ Douglas Kelly, The Arts of Poetry and Prose, Typologie des Sources du Moyen Âge Occidental, 59 (Turnhout: Brepols, 1991), pp. 41-42. 
priests, heralds, or messengers; the coma, colon, and period serve as her chancellor, treasurer, and dispenser of alms; and dictamen, as her steward, greeter, and master of the banquet. Philomela, always a figure of eloquent language, is her secretary. This allegorical drama perhaps becomes less mysterious if we consider that, for students of dictamen, the habitus of Rhetoric could be translated into the livery of a dependent clerk: the students who respond to Queen Rhetoric's invitations could hope to become administrative servants in non-allegorical houses. By their very existence, artes dictandi implicitly promise the student a remunerative future. However, the allegorical frame in Regina sedens rhetorica does something more: it resignifies all the characteristic signs of the remunerative position for which it prepares its students. Once resignified, each sign of patronage - livery, nobility, the royal hall - appears to signify nothing more than the cultural capital, or eloquence, on account of which a student hoped to acquire a patron. All the elements of the patronage economy are elevated into the heavens of rhetorical elegance so that they might then descend back to earth and confer a transcendent value on the lord who provides the skillful and eloquent clerk with a living. Rhetorical skill gives the clerk a socially credible claim to a position at court, but simultaneously implies that this position is only a secondary recognition of a value that precedes, transcends, and maintains the credibility of the patrons who recognized it. By recognizing and remunerating valuable things, the patronage system claimed transcendent values for itself and secured its legitimacy in the eyes of all those who recognized the same values.

To the question 'What did the cursus mean for students of dictamen?' no answer can be given. Instead, I have attempted to notice and describe a variety of effects which the cursus occasions or provokes in the texts that teach it. For the composite treatise Cum inter iocunda, the cursus occasions graceful condescension. By means of graceful condescension, the author inserts a comfortable distance between himself and a subject which, in the context of monastic devotion or comprehensive rhetorical teaching, should perhaps not be taken too seriously. By contrast, Simon O.'s Summa dictaminis betrays no such moderation in its relationship to this feature of ars dictaminis. Finally, in Regina sedens rhetorica, cursus opens a dance of Freudian denial: what the treatise simultaneously denies and expresses through the screen of allegory is the link between literate skill and the economics of patronage. Together, these three treatises show that the cursus was less an intrinsically meaningful element within a symbolic universe than a quilting point for an experience of the social world, a point of attachment for 
what Bourdieu termed 'social libido'. ${ }^{109}$ For us, the interest of these treatises and their presentation of cursus is as evidence for an historical experience and its structuration. ${ }^{110}$

${ }^{109}$ Bourdieu, The Rules of Art, p. 172.

110 This essay has benefited greatly from comment and criticism, especially from Martin Camargo, Rita Copeland, Eleanor Johnson, Traugott Lawler, Law rence Manley, Alastair Minnis, Catherine Nicholson, Aaron Ritzenburg, David Wallace, and Michael Warner, and from participants in the Yale Medieval-Renaissance Colloquium. I am especially grateful to Martin Camargo for sharing his knowledge, including unpublished work, so generously at several key points in the development of this project. Responsibility for errors of fact and judgement is mine alone. 